\title{
Effects of climate and nutrient load on the water quality of shallow lakes assessed through ensemble runs by PCLake
}

\author{
Anders Nielsen, ${ }^{1,2,3,8}$ Dennis Trolle, ${ }^{1,2}$ Rikke Buerring, ${ }^{1}$ Martin Søndergaard, ${ }^{1}$ J $\emptyset$ rgen E. Olesen, ${ }^{2,3}$ \\ Jan H. Janse, ${ }^{5}$ Wolf M. Mooij, ${ }^{6,7}$ And Erik JePpesen ${ }^{1,2,4}$ \\ ${ }^{1}$ Department of Bioscience, Aarhus University, Vejlsøvej 25, 8600 Silkeborg, Denmark \\ ${ }^{2}$ Sino-Danish Centre for Education and Research, Beijing, China \\ ${ }^{3}$ Department of Agroecology, Aarhus University, Blichers Allé 20, 8830 Tjele, Denmark \\ ${ }^{4}$ Greenland Climate Research Centre, Greenland Institute of Natural Resources, Kivioq 2, Nuuk, Greenland and Arctic Centre, \\ Aarhus University \\ ${ }^{5}$ PBL Netherlands Environmental Assessment Agency, NL-3720AH Bilthoven, The Netherlands \\ ${ }^{6}$ Netherlands Institute of Ecology, Department of Aquatic Ecology, 6700AB Wageningen, The Netherlands \\ ${ }^{7}$ Wageningen University, Department of Aquatic Ecology and Water Quality Management, AA Wageningen, The Netherlands
}

\begin{abstract}
Complex ecological models are used to predict the consequences of anticipated future changes in climate and nutrient loading for lake water quality. These models may, however, suffer from nonuniqueness in that various sets of model parameter values may yield equally satisfactory representations of the system being modeled, but when applied in future scenarios these sets of values may divert considerably in their simulated outcomes. Compilation of an ensemble of model runs allows us to account for simulation variability arising from model parameter estimates. Thus, we propose a new approach for aquatic ecological models creating a more robust prediction of future water quality. We used our ensemble approach in an application of the widely used PCLake model for Danish shallow Lake Arreskov, which during the past two decades has demonstrated frequent shifts between turbid and clear water states. Despite marked variability, the span of our ensemble runs encapsulated $70-90 \%$ of the observed variation in lake water quality. The model exercise demonstrates that future warming and increased nutrient loading lead to lower probability of a clear water, vegetation-rich state and greater likelihood of cyanobacteria dominance. In a $6.0^{\circ} \mathrm{C}$ warming scenario, for instance, the current nutrient loading of nitrogen and phosphorus must be reduced by about $75 \%$ to maintain the present ecological state of Lake Arreskov, but even in a near-future $2.0^{\circ} \mathrm{C}$ warming scenario, a higher probability of a turbid, cyanobacteriadominated state is predicted. As managers may wish to determine the probability of achieving a certain ecological state, our proposed ensemble approach facilitates new ways of communicating future stressor impacts.
\end{abstract}

Key words: climate change; ensemble modeling; Funen, Denmark; Lake Arreskov; lake water quality; PCLake.

\section{INTRODUCTION}

Ecological lake models have been developed for decades for management and research purposes (Jørgensen and Bendoricchio 2001, Trolle et al. 2012), and several complex dynamic lake models are presently available (for a recent review see Mooij et al. [2010]). These models can be used as experimental tools for both managers and scientists (Jørgensen 1994, Schmolke et al. 2010) and facilitate ways to assess impacts on lake water quality under various scenario forcings. Thus, models can be potent tools for assessing potential synergistic effects of nutrient loading and climate change on lakes. Lake water quality across the world has deteriorated in recent decades, and many

Manuscript received 30 April 2013; revised 14 April 2014; accepted 17 April 2014; final version received 13 May 2014 Corresponding Editor: E. H. Stanley.

8 E-mail: civil05@gmail.com lakes have become eutrophic as a result of excessive nutrient input from anthropogenic activities (Jin et al. 2005, Smith and Schindler 2009), with detrimental consequences for biological diversity (Jeppesen et al. 2000) and human use of water resources (Falconer and Humpage 2005). Climate changes may amplify the impacts of eutrophication (Jeppesen et al. 2010, Moss et al. 2011), hamper restoration attempts (Jeppesen et al. 2009), and lead to dominance of potentially toxinproducing cyanobacteria (Delpla et al. 2009, Jeppesen et al. 2009, Kosten et al. 2012). Observed changes in climate include pronounced increases in air temperature since the 1970s (Trenberth et al. 2007), and emissions of greenhouse gasses (Olivier et al. 2012) are continuously narrowing the gap between the current climate and the internationally agreed targets for tolerable warming (Meinshausen et al. 2009, Stocker 2013). Hence, we are already facing deteriorated aquatic ecosystems under additional stress from 
climate change, at a time when aquatic ecosystems are becoming increasingly important sources of freshwater needed to support a growing global population with increasing wealth (UN 2012).

Model assessments of future lake water quality in response to changes in nutrient loading and climate have recently been made (e.g., Elliott et al. 2006, Mooij et al. 2007, Trolle et al. 2011), providing managers with estimates of the effects of potential management actions intended to mitigate impacts of climate change. However, when models are used as predictive tools, they are extrapolated beyond their calibrated domain by assuming that satisfactory model performance and model parameter value settings under current conditions facilitate a plausible projection of the future. This assumption is logically applied because of natural constraints on the possibilities of validating model performance for a given future state (Refsgaard et al. 2013). Few studies (e.g., Arhonditsis et al. 2008) have attempted to address the effects of parameter uncertainty on model simulations using relatively simple models $(<20$ model parameters) and allowing model parameters to vary within given statistical distributions. This approach has not been adapted and applied to more commonly used state-of-the-art complex lake ecosystem models ( $>100$ parameters), such as DYRESM-CAEDYM, PCLake, or PROTECH (Trolle et al. 2012a). Moreover, given the high amount of adjustable model parameters in complex ecosystem models, these will also be subject to nonuniqueness (Beven 2006). As summarized in Beven (2006), nonuniqueness (also known as equifinality) in the context of modeling addresses the potential of multiple combinations of model parameter values being equally representative of or optimal for the system being modeled. Hence, no single set of model parameter values provides superior model performance relative to other combinations. Therefore, several combinations of parameter values may yield an equally satisfactory model performance under current conditions but may potentially divert in their simulated outcomes when scenarios of the future are applied beyond their calibrated domain.

We embrace the concept of nonuniqueness and propose a new way forward in complex lake model studies with execution of multiple model runs based on a range of model parameter values. Our objective was to assess the variability in simulated model outcomes created by model parameter uncertainty and to translate this variability into scenario simulations, thus elucidating the impacts and uncertainty of several potential scenarios of future warming and nutrient loads on lake water quality. Our approach was implemented in the widely used PCLake model (Janse and van Liere 1995) set up for shallow Danish Lake Arreskov, on which a unique 18-year data set is available, covering highly variable lake water quality and ecological states representing a challenge to any lake model.

\section{Methods}

Study site

Lake Arreskov is a Danish shallow lake with a mean depth of $1.9 \mathrm{~m}$, a maximum depth of $3.6 \mathrm{~m}$, a surface area of $3.17 \mathrm{~km}^{2}$, a volume of 5.9 million $\mathrm{m}^{3}$, and a hydraulic retention time of approximately $1.1 \mathrm{yr}$ (Liboriussen et al. 2007). The lake is located in the upper part of the River Odense watershed on the island of Funen, Denmark $\left(55.16^{\circ} \mathrm{N}, 10.31^{\circ} \mathrm{E}\right), 32 \mathrm{~m}$ above sea level (Fig. 1). The climate is temperate with an annual mean precipitation of $753 \mathrm{~mm}(1990-2010)$ and a mean winter (October-April) and summer (May-September) temperature of $4.5^{\circ} \mathrm{C}$ and $14.9^{\circ} \mathrm{C}$, respectively. The watershed $\left(24.8 \mathrm{~km}^{2}\right.$ excluding the lake area, elevation difference of $84 \mathrm{~m}$ within the watershed) is dominated by agriculture (45\%) and forests (32\%) with loamy sand soils (Nielsen et al. 2000; see Fig. 1). Common alder (Alnus glutinosa) and common ash (Fraxinus excelsior) scrubs surround the majority of the littoral zone of the lake. The lake is the largest in this region and receives water from 13 tributaries, one-half of which are artificially constructed to drain lowland areas. Since 1989, the lake has been a part of the National Monitoring and Assessment Program for the Aquatic and Terrestrial Environment in Denmark (NOVANA) (Kronvang et al. 1993) entailing submonthly samplings ( $n=19$ samples/yr) of lake water quality and bimonthly sampling of flow and nutrient concentrations in the three major tributaries (Fig. 1). Submerged vegetation coverage (Veg) has been monitored annually from 1993 to 2008 (Fyns Amt 2006) at biomass maximum.

In the 1950-1980s, the lake received untreated sewage from the nearby town of Korinth (970 person equivalents), which caused severe eutrophication. The sewage was diverted in 1983 (Fyns Amt 2006). From 1989 to 1997, commercial fishing, active removal of cyprinid fish, mainly roach (Rutilus rutilus) and bream (Abramis brama), and stocking of piscivore fingerlings (pike, Esox lucius) was undertaken (Sandby 1998, Fyns Amt 2006, Søndergaard et al. 2007), partly with the aim of restoring the lake to a clear water state. To further reduce the external nutrient loading, wetlands were established adjacent to the largest tributaries in 2003 $\left(0.39 \mathrm{~km}^{2}\right.$, Geddebækken $)$ and $2005\left(0.1 \mathrm{~km}^{2}\right.$, Hammerdam), receiving water routed by subsurface drains from some of the cultivated areas in the watershed (Hoffmann et al. 2004, Hansen et al. 2011); see Fig. 1). In 2005, the practice of water level regulation at the outlet was modified to sustain discharges throughout summer when phosphorus concentrations were typically higher (Fyns Amt 2006).

After reductions in fish density, water clarity improved markedly, as Secchi depth increased $>1.5 \mathrm{~m}$, and submerged aquatic vegetation coverage expanded from near absence to $60 \%$ of the lake area. Consequently, zooplankton (Zoo, expressed as dry matter throughout the present study) became dominated by large-bodied 
Daphnia. A few years later, however, cyanobacteria bloomed again with a consequent decline in submerged vegetation, reaching a minimum in 1999. In the following years (1999-2004), cyanobacteria blooms occurred each summer. Following implementation of the modified water level regulation procedure in 2005 , water quality improved again, and summer mean nutrient concentrations (total phosphorus [TP] and total nitrogen [TN]) and chlorophyll $a$ (chl $a$ ) decreased. In general, Lake Arreskov has shown large interannual variations in ecological state, shifting between clear water and turbid states, which is typical for shallow lakes at intermediate high nutrient levels (Scheffer et al. 1993). Thus, high water clarity and high abundance of Veg have been observed in some years (i.e., 1997, 2005, and 2006), while turbid waters, loss of Veg, and dominance of cyanobacteria have been observed in other years (i.e., 1999, 2000, and 2004). Consequently, summer mean concentrations of chl $a$ have varied substantially; for example, values in 2003 were 14 times higher $(173 \mu \mathrm{g} / \mathrm{L})$ than in $1997(12 \mu \mathrm{g} / \mathrm{L})$.

\section{PCLake model}

PCLake (Janse and van Liere 1995) is an integrated ecological model developed for shallow nonstratifying lakes and operates with a fully mixed water column and a subsurface sediment layer. The model was developed for estimating critical loadings for transitions between the clear, vegetation-dominated state and the turbid, phytoplankton dominated state in shallow lakes (Janse 1997, Janse et al. 2008). We selected this particular model as it is the only one described in the existing literature that is able to account for interactions between macrophyte recovery and decay (as has been observed multiple times in Lake Arreskov) and fish, zooplankton, and phytoplankton in shallow lakes. The model includes three groups of phytoplankton (diatoms, green algae, and cyanobacteria), zooplankton, submerged vegetation, and three functional groups of fish (zooplanktivorous, benthivorous, and piscivorous), and the dynamics between these components (e.g., grazing, predation, and shade effects), as well as implications for sediment resuspension. Diatoms may be constrained by silicate, whereas other organisms may be limited by nitrogen, phosphorus, light, or temperature (Janse 2005). Zooplankton grazing efficiency varies between the phytoplankton groups and is lowest for cyanobacteria (Janse and Aldenberg 1990). Apart from mechanistic descriptions of biotic and abiotic processes, PCLake includes empirically based linear relations between resuspension and fish, between resuspension and vegetation, and between vegetation and growth of piscivorous fish.

Configuration of model boundary conditions.-The model inputs include lake mean water depth (m), fetch $(\mathrm{m})$, nutrient loading $\left(\mathrm{g} \cdot \mathrm{m}^{-2} \cdot \mathrm{d}^{-1}\right)$, water inflow and outflow (precipitation, groundwater infiltration, and seepage; $\mathrm{mm} / \mathrm{d})$, evaporation $(\mathrm{mm} / \mathrm{d})$, wind speed $(\mathrm{m} /$ $\mathrm{s})$, radiation $\left(\mathrm{J} \cdot \mathrm{m}^{-2} \cdot \mathrm{d}^{-1}\right)$, and water temperature $\left({ }^{\circ} \mathrm{C}\right)$.
We used the water inflow monitored on a daily basis in the three major tributaries covering $30 \%$ of the watershed (Fig. 1, hatched areas draining to stations 1-3), with missing data being replaced by linear regressions predicted from a relationship with observations in the outflow (station 4). Inflow from the remaining ungauged part of the watershed, as well as groundwater seepage, were included in a residual derived from a water balance using measured inflow, outflow, precipitation, and estimated evaporation. Evaporation was calculated according to Imerito (2007) from elevation above sea level, relative humidity, wind speed, and temperature in air and water. Climate variables were daily observations provided by the Danish Meteorological Institute (DMI) on a national $10-\mathrm{km}$ (precipitation) or $20-\mathrm{km}$ (wind speed and temperature) climate grid scale (Cappelen et al. 2007), except for relative humidity which was obtained from a DMI station $\left(56.30^{\circ} \mathrm{N}, 09.12^{\circ} \mathrm{E}\right)$. Concentrations of nitrogen $(\mathrm{N})$ and phosphorus $(\mathrm{P})$ have been measured bimonthly at the inflow stations (Fig. 1, stations 1-3), and we replaced missing data by relationships with available nutrient concentrations in the same or in adjacent inflows, whereas silica was represented by a mean constant concentration based on available existing observations (1989-1993). Nutrient concentrations in the water inflow from the ungauged part of the watershed, constituting approximately $30 \%$ of the total inflow, were represented by average flow-weighted concentrations derived from stations 1-3. All chemistry and flow data were interpolated linearly to daily values for each station. Subsequently, organic $\mathrm{N}$ and $\mathrm{P}$ were calculated as the difference between total nutrient concentrations and inorganic fractions. In addition to external tributary nutrient loads, atmospheric deposition was included as $16.6 \mathrm{~kg} \mathrm{~N} \cdot \mathrm{ha}^{-1} \cdot \mathrm{yr}^{-1}$ according to Ellermann et al. (2010), which is based on estimations by the Danish eulerian hemisphere model (DEHM). Biomanipulation was implemented as a constant daily rate of fish removal $(0.007 /$ d) from January to July 1995 to reflect historical fish removal effects on water quality (Liboriussen et al. 2007). As calculation of water temperature from global radiation is not included in PCLake, we computed a vertical integrated water temperature by the hydrodynamic lake model DYRESM (Hamilton and Schladow 1997, Imerito 2007) to serve as input to PCLake.

Observed in-lake water quality.-We evaluated model performance against observed data for the following inlake (see Fig. 1, station 5) water quality variables: chl $a$, TN, TP, Zoo, and Veg. As prescribed in NOVANA, lake chemistry data and phytoplankton are sampled in a water column representing twice the Secchi depth (Lauridsen et al. 2007), and examination of the Lake Arreskov data set revealed that peak values of chl $a$ were typically sampled close to the surface $(<0.6 \mathrm{~m})$. However, PCLake computes a zero-dimensional system with homogeneous concentrations vertically and horizontally and can thus not account for possible near-surface accumulations. To 


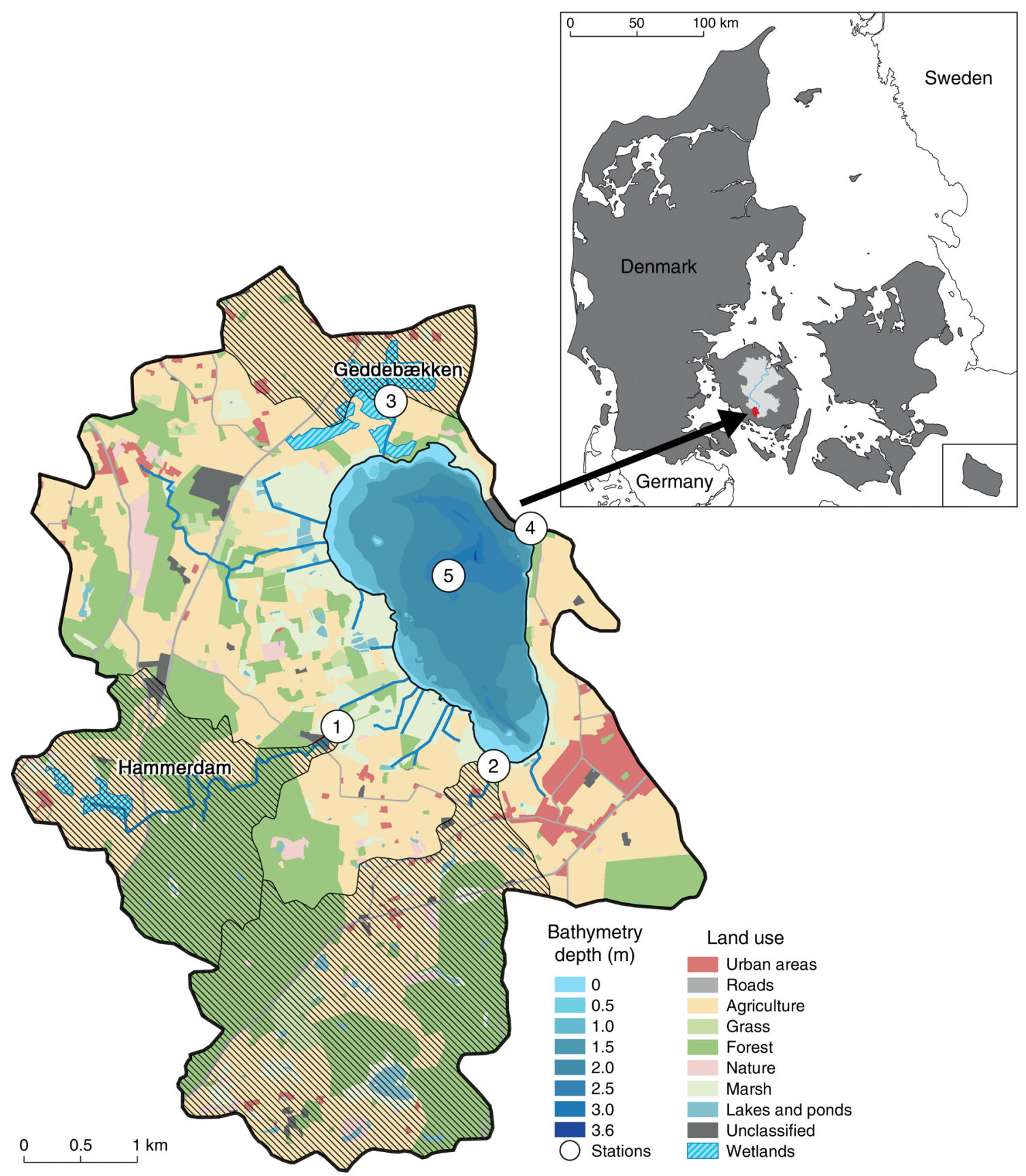

FIG. 1. A map of the study area, where hatched lines represent the watershed fraction (30\%) draining to the hydrometric monitoring stations 1-3; stations 4 and 5 are outflow and in-lake observation locations, respectively. Land use classifications are derived from Nielsen et al. (2000). Insert map shows the location of the lake in the southern part of the River Odense watershed (light gray polygon).

illustrate this limitation, we examined the PCLake model error as the absolute deviation (AD) between modeled output and observations for chl $a$, TP, and TN as a function of observation sampling depth. Observations $(n=$ 347, from 1992 to 2009) were averaged for discrete sampling depths in the data set $(n=81$ discrete depths ranging between 0.2 and $3.5 \mathrm{~m}$ for $\mathrm{TN}$ and $\mathrm{TP}$, and 0.2 to $2.1 \mathrm{~m}$ for $\operatorname{chl} a$ ). A fitted power function (PROC NLIN, statistical software SAS 9.3) showed relationships for chl $a$ $\left(\mathrm{AD}=50.89\left[\mathrm{depth}^{-1.06}\right] ; R^{2}=0.39\right)$ and TP $(\mathrm{AD}=$ $0.067\left[\mathrm{depth}^{-0.59}\right] ; R^{2}=0.17$ ), whereas a linear relationship with depth, as best fit for TN, showed a weak relationship $\left(\mathrm{AD}=-0.21\right.$ depth $\left.+1.18 ; R^{2}=0.05\right)$.

For chl $a$ (Fig. 2), the increase in AD with decreasing sampling depth may be attributed to the relatively high proportion of cyanobacteria in the lake, forming surface 


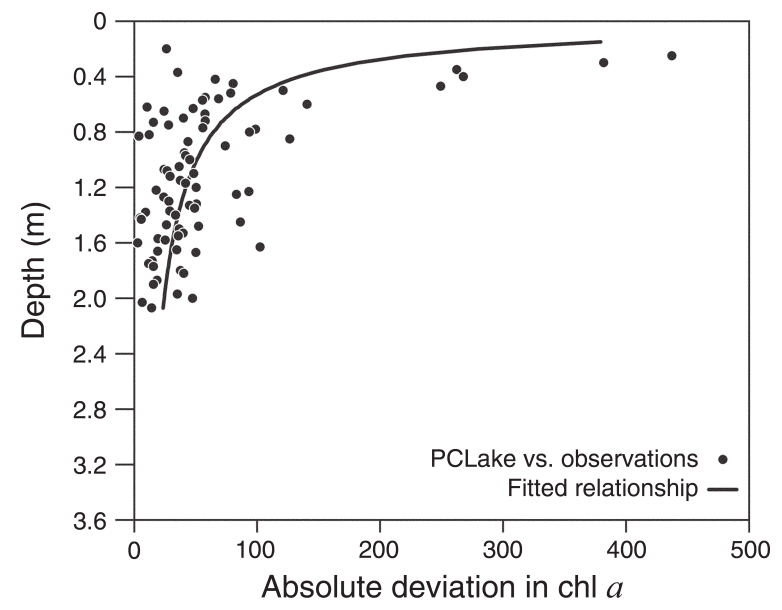

FIG. 2. Absolute deviation (AD) in chlorophyll $a$ (chl $a$ ), $\mu \mathrm{g} / \mathrm{L}$, between PCLake model output and observations as a function of sampled depth. Observations $(n=347$, from 1992 to 2009) were averaged with respect to discrete sampling depths in the data set. The line represents a fitted power function.

blooms during calm and warm periods due to their buoyancy control regulated by gas vacuoles (Paerl and Huisman 2008). Some water quality variables (e.g., chl $a$, TP, and TN) may therefore exhibit vertical gradients with near-surface peak values, which is conceptually out of reach for the model. Hence, observations close to the surface $(<0.6 \mathrm{~m}$ being the threshold where model estimates deviated considerably from observations; see Fig. 2) were considered not representative for the system simulated by PCLake and were not given any weight in the calibration procedure and thus omitted from the statistical evaluation of the model. However, to illustrate the contrast between the conceptual model capability and the real lake system, we included the full data set in plots.

PCLake calibration.-PCLake model parameters are by default tuned with respect to observed water quality in $>40$ lakes (Janse 2005), but adjustments of a range of parameters proved necessary to achieve adequate performance with the site-specific boundary conditions applied for Lake Arreskov for the study period 19922009. Twenty-two parameters were initially adjusted manually to achieve reasonable model representation of water quality dynamics with respect to timing and magnitude of water quality variables. The parameters were identified and selected from previous sensitivity analyses described in Janse et al. (2010) and user experiences with the current model setup for Lake Arreskov. To evaluate model performance, we computed the mean absolute relative error (RE) and coefficient of determination $\left(R^{2}\right)$ between observed water quality and model output on daily, monthly, seasonal, and yearly timescales. Our statistics were then compared with those of Arhonditsis and Brett (2004) who reviewed model performances from 153 case studies.
Sensitivity analysis.-Following the initial manual calibration, we performed a one-at-a-time sensitivity analysis to examine the sensitivity of each individual model parameter adjustable in calibration $(n=350)$. Sensitivity was quantified with respect to impact on simulated water quality variables (chl $a, \mathrm{TN}, \mathrm{TP}, \mathrm{Veg}$, and Zoo) represented by summer mean concentrations averaged across the full time series (i.e., 1992-2009). Three model runs were performed for each parameter: (1) initial parameter value, (2) $+25 \%$ from the initial parameter value, and (3) $-25 \%$ from the initial parameter value, while all other parameters were kept constant. For each parameter the most sensitive model run of either (2) or (3) was identified as the one with the largest deviation from the model run (1). For each of the five water quality variables, the sensitivity output, allocated to the parameters, was normalized and ranked, and the most sensitive parameters for each water quality variable were defined as those contributing to the top $10 \%$ (90th percentile) of variation in the model output.

Parameter uncertainty.-Based on identification of sensitive parameters (Table 1), we expanded the ordinary PCLake version to allow random parameter value sampling and automatic model execution. These modifications were implemented in the PCLake version described in Mooij et al. (2010), which is executed through a Microsoft Excel interface. We implemented a batch iteration procedure which allowed 900 automatic model runs (maximum allowed in the current Excel setup). We also trialed multiple batch runs allowing 2000 simulations and found that the range in simulated output did not change significantly from running 900 simulations. For each run, the model parameters contributing to the top $10 \%$ of variation in the model output values were sampled randomly by the Excel RAND-function within a fixed range defined as a $\pm 20 \%$ deviation from their default or initially adjusted value. This range was the widest allowed for successful model simulations, implying that no model simulation crashed due to parameters being out of range. To visualize the simulated uncertainty caused by parameter variability, we extracted the 5th and the 95th percentiles of simulated water quality variables on a daily time step from the 900 model runs and plotted the statistics as uncertainty bands around the initially adjusted model simulation line.

\section{Ecological regimes and variability}

To examine the model's capability to render the ecological regimes (types) of both stable states and transitions between states, four types were defined (Fig. 3), encompassing two steady state types with and without submerged vegetation in all years $(n=18)$ and two transition types exhibiting either a marked reduction in vegetation coverage or a marked increase in vegetation coverage between two neighboring years. Consequently, all model runs in our ensemble were 
subdivided and examined according to these criteria that were all assumed to be plausible representations of the variable ecosystem of the lake. The lake has exhibited both states of transition across the 18-year period. Consequently, each individual model run was allowed to be classified as both types of transition to express the natural variability in the lake. For each batch of ensemble simulations, water quality variables were seasonally averaged for the summer, and for each of the four lake types the 5th, 25th, 50th, 75th, and 95th percentiles were computed to reflect the variability in the current state and when applying future scenarios. To elucidate the changes in state for the transition lake types, exhibiting either vegetation decrease (type 3 ) or vegetation increase (type 4), we computed the relative change in mean summer concentrations at the time of transition.

\section{Scenarios}

To assess the effects of future changes in climate and land use (proxied through nutrient loading) on lake water quality, we applied various projections with uniform transformation of climate and nutrient loading across seasons (i.e., delta change method). Hence, daily water temperatures were increased by $0.5^{\circ} \mathrm{C}, 2.0^{\circ} \mathrm{C}$, and $6.0^{\circ} \mathrm{C}$ (ranging from low to extreme warming in the scenarios outlined in the IPCC assessment reports), respectively, whereas the daily nutrient loading of both $\mathrm{N}$ and $\mathrm{P}$ was increased or decreased by $75 \%$, respectively, combined with the warming scenarios. The span in temperature and nutrient loading was chosen to force scenario signals for later interpretation. While the nutrient load scenarios may seem dramatic, these are in fact reflecting the magnitude changes that many eutrophic lakes have undergone in developed countries. For example, a typical historical development in the loads of a Danish lake is well documented for Lake Fure (e.g., Sand-Jensen et al. 2008), where loads increased 30 fold from 1900 to 1970 (mainly due to increasing sewage discharges, intensified agriculture, and the use of phosphorus-based detergents) and then (due to management of external sources) declined to twice the levels of 1970 in 2005. The 900 sets of parameter values, sampled to form the variety of runs in our ensemble under current conditions, were retained and utilized in the scenario simulations. For each scenario, the ensemble runs were categorized according to the type of classification in Fig. 3, and the relative fraction of the four types was computed and compared between scenarios where the sum of classified types may vary between scenarios. As alterations in the occurrence of cyanobacteria blooms draw special attention when assessing effects of climate changes due to their potential toxin production (Paerl and Huisman 2008), we also computed the proportion of cyanobacteria predicted by the model.
RESULTS

\section{Sensitivity analysis}

Several parameters $(n=43)$ were identified as sensitive (Table 1), accounting for the top $10 \%$ of variation in the model output, 29 of which were sensitive to all five water quality variables (Fig. 4). Overall, the temperature constant of mineralization in water (cThetaMinW) was identified as the most sensitive parameter, followed by the temperature constant for mineralization in the sediment (cThetaMinS). For chl $a$ (cExtSpBlue), Zoo (cMuMaxDiat), and TP (cTurbDifNut, fRedMax, and kPDifPO4), individual parameters proved sensitive to these variables, whereas all parameters sensitive to $\mathrm{TN}$ proved to be sensitive to other water quality variables (Table 1). Especially for TP, the parameter controlling the reduction factor of $\mathrm{P}$ adsorption (fRedMax) was highly sensitive (Fig. 4), whereas the sensitivity for the remaining water quality variables was more equally distributed among the parameters. Among the sensitive parameters (Table 1), $26 \%$ proved to be sensitive to zooplankton-related dynamics and $19 \%$ to vegetationrelated dynamics, whereas parameters allocated to nutrient dynamics constituted the lowest fraction (12\%). In general, parameters (cQ10ProdVe, cQ10RespVeg, cSigTmBlue, cSigTmFish, cSigTmZoo, cThetaMinS, cThetaMinW, cTmOptBlue, cTmOptFish, and cTmOptZoo) specifying influences of temperature (such as rate constants that infer exponential responses) constituted $23 \%$ of the most sensitive parameters.

\section{Lake water quality}

For the initial manually adjusted model, low $R^{2}$ values were generally achieved for all water quality variables across all temporal scales (i.e., daily, monthly, seasonally, and yearly), ranging between $<0.01-0.21$ and being strongest, albeit nonsignificant $(P>0.05)$, for yearly averages (Table 2). Although $R^{2}$ values were low, simulated output showed marked dynamics across seasons and between years, generally of similar magnitude as in lake observations. Hence, yearly simulated peak values of each individual water quality variable showed more than a two-fold difference between the highest and lowest peak concentration of chl $a$ (range in maxima, $84-183 \mu \mathrm{g} / \mathrm{L}$ ), Zoo (range in maxima, 1.7-3.6 $\mathrm{mg} / \mathrm{L}$ ), and TP (range in maxima, $0.07-0.2 \mathrm{mg} / \mathrm{L}$ ) across the entire period of time (1992-2009) and an even greater difference for TN (range in maxima, $1.4-4.2 \mathrm{mg}$ / L) and Veg (range in maxima, 1.6-57\% coverage), as illustrated in Fig. 5. RE ranged between 26-110\%, with a tendency towards a decrease from daily to yearly averages. The lowest RE was found for TN (yearly averages, 26\%) and the highest for chl $a$ (daily averages, $110 \%$ ), and the abiotic water quality variables (TN and TP) generally had lower values RE than the biotic variables (Table 2). 
TABLE 1. Characteristics of parameters identified as (A) sensitive $(n=43)$, sorted according to internal model identity (ID), and (B) parameters adjusted initially $(n=7)$ but not identified as sensitive.

\begin{tabular}{|c|c|c|c|c|c|c|c|c|c|c|}
\hline \multirow[b]{2}{*}{ Parameter ID } & \multirow[b]{2}{*}{ Unit } & \multicolumn{2}{|c|}{ Parameter value } & \multirow[b]{2}{*}{ Description } & \multicolumn{5}{|c|}{ Sensitivity allocation } & \multirow[b]{2}{*}{ Sensitivity } \\
\hline & & Default & Adjusted & & $\mathrm{Chl} a$ & $\mathrm{TN}$ & $\mathrm{TP}$ & Veg & $\mathrm{Zoo}$ & \\
\hline \multicolumn{11}{|l|}{ A) Sensitive } \\
\hline 52, cDayWinVeg & d & 259 & $\cdots$ & $\begin{array}{l}\text { end of growing season on } \\
16 \text { September }\end{array}$ & $\mathrm{x}$ & $\mathrm{x}$ & $\mathrm{x}$ & $\mathrm{x}$ & $\mathrm{x}$ & $\dagger \dagger$ \\
\hline 54, cDCarrBent & & 10 & $\cdots$ & $\begin{array}{l}\text { carrying capacity of } \\
\text { benthos }\end{array}$ & $\mathrm{x}$ & $\mathrm{x}$ & $\mathrm{x}$ & $\mathrm{x}$ & $\mathrm{x}$ & $\dagger \dagger$ \\
\hline 55, cDCarrFish & $\mathrm{g} \mathrm{DM} / \mathrm{m}^{2}$ & 15 & $\ldots$ & carrying capacity of fish & $\mathrm{x}$ & $\mathrm{x}$ & $\mathrm{x}$ & $\mathrm{x}$ & & $\dagger$ \\
\hline 60, cDCarrZoo & $\mathrm{mg} / \mathrm{L}$ & 25 & $\cdots$ & $\begin{array}{l}\text { carrying capacity of } \\
\text { zooplankton }\end{array}$ & $\mathrm{x}$ & $\mathrm{x}$ & $\mathrm{x}$ & $\mathrm{x}$ & $\mathrm{x}$ & $\dagger$ \\
\hline 80, cExtSpBlue & $\mathrm{m}^{2} / \mathrm{g} \mathrm{DM}$ & 0.35 & $\cdots$ & $\begin{array}{l}\text { specific extinction of } \\
\text { bluegreens }\end{array}$ & $\mathrm{x}$ & & & & & $\dagger$ \\
\hline 91, cFiltMax & $\underset{\mathrm{L} \cdot \mathrm{mg}}{\mathrm{DM}}$ & 4.5 & 3.8 & maximum filtering rate & $\mathrm{x}$ & $\mathrm{x}$ & $\mathrm{x}$ & $\mathrm{x}$ & $\mathrm{x}$ & $\pitchfork \dagger \dagger$ \\
\hline 104, cMuMaxBlue & $\mathrm{d}^{-1}$ & 0.6 & 0.68 & $\begin{array}{l}\text { maximum growth rate of } \\
\text { bluegreens }\end{array}$ & $\mathrm{x}$ & $\mathrm{x}$ & $\mathrm{x}$ & $\mathrm{x}$ & $\mathrm{x}$ & $\dagger \dagger$ \\
\hline 105, cMuMaxDiat & $d^{-1}$ & 2 & 1.9 & $\begin{array}{l}\text { maximum growth rate of } \\
\text { diatoms }\end{array}$ & & & & & $\mathrm{x}$ & $\dagger$ \\
\hline 107, cMuMaxVeg & $d^{-1}$ & 0.2 & 0.24 & $\begin{array}{l}\text { maximum growth rate of } \\
\text { vegetation at } 20^{\circ} \mathrm{C}\end{array}$ & $\mathrm{x}$ & $\mathrm{x}$ & $\mathrm{x}$ & $\mathrm{x}$ & $\mathrm{x}$ & ††† \\
\hline 151, coPO4Max & $\mathrm{mg} \mathrm{P} / \mathrm{L}$ & 1 & $\cdots$ & $\begin{array}{l}\text { maximum SRP } \\
\text { concentration in pore } \\
\text { water }\end{array}$ & & & $\mathrm{x}$ & & $\mathrm{x}$ & $\dagger$ \\
\hline 188, cPrefBlue & & 0.125 & 0.226 & $\begin{array}{l}\text { selection factor for } \\
\text { bluegreens }\end{array}$ & $\mathrm{x}$ & $\mathrm{x}$ & $\mathrm{x}$ & $\mathrm{x}$ & $\mathrm{x}$ & $\dagger$ \\
\hline 189, cPrefDet & & 0.25 & $\cdots$ & $\begin{array}{l}\text { selection factor for } \\
\text { detritus }\end{array}$ & $\mathrm{x}$ & $\mathrm{x}$ & $\mathrm{x}$ & $\mathrm{x}$ & $\mathrm{x}$ & †† \\
\hline 190, cPrefDiat & & 0.75 & 0.85 & $\begin{array}{l}\text { selection factor for } \\
\text { diatoms }\end{array}$ & & $\mathrm{x}$ & $\mathrm{x}$ & $\mathrm{x}$ & $\mathrm{x}$ & $\dagger$ \\
\hline 194, cQ10ProdVeg & & 1.2 & $\cdots$ & $\begin{array}{l}\text { temperature quotient of } \\
\text { production }\end{array}$ & $\mathrm{x}$ & $\mathrm{x}$ & $\mathrm{x}$ & $\mathrm{x}$ & $\mathrm{x}$ & †† \\
\hline 196, cQ10RespVeg & & 2 & $\cdots$ & $\begin{array}{l}\text { temperature quotient of } \\
\text { respiration }\end{array}$ & $\mathrm{x}$ & $\mathrm{x}$ & $\mathrm{x}$ & $\mathrm{x}$ & $\mathrm{x}$ & †† \\
\hline 221, cSigTmBlue & ${ }^{\circ} \mathrm{C}$ & 12 & $\cdots$ & $\begin{array}{l}\text { temperature constant of } \\
\text { bluegreens }\end{array}$ & $\mathrm{x}$ & $\mathrm{x}$ & $\mathrm{x}$ & $\mathrm{x}$ & $\mathrm{x}$ & $\dagger \dagger$ \\
\hline 223, cSigTmFish & ${ }^{\circ} \mathrm{C}$ & 10 & $\cdots$ & $\begin{array}{l}\text { temperature constant of } \\
\text { fish }\end{array}$ & $\mathrm{x}$ & $\mathrm{x}$ & $\mathrm{x}$ & $\mathrm{x}$ & $\mathrm{x}$ & †† \\
\hline 227, cSigTmZoo & ${ }^{\circ} \mathrm{C}$ & 13 & $\cdots$ & $\begin{array}{l}\text { temperature constant of } \\
\text { zooplankton }\end{array}$ & $\mathrm{x}$ & $\mathrm{x}$ & $\mathrm{x}$ & $\mathrm{x}$ & $\mathrm{x}$ & ††† \\
\hline 231, cSuspRef & & 0.5 & $\cdots$ & constant for resuspension & $\mathrm{x}$ & $\mathrm{x}$ & $\mathrm{x}$ & $\mathrm{x}$ & $\mathrm{x}$ & $\dagger \dagger$ \\
\hline 235, cThetaMinS & & 1.07 & $\cdots$ & $\begin{array}{l}\text { exponential temperature } \\
\text { constant of } \\
\text { mineralization in } \\
\text { sediment }\end{array}$ & $\mathrm{x}$ & $\mathrm{x}$ & $\mathrm{x}$ & $\mathrm{x}$ & $\mathrm{x}$ & ††† \\
\hline 236, cThetaMinW & & 1.07 & $\cdots$ & $\begin{array}{l}\text { exponential temperature } \\
\text { constant of } \\
\text { mineralization in water }\end{array}$ & $\mathrm{x}$ & $\mathrm{x}$ & $\mathrm{x}$ & $\mathrm{x}$ & $\mathrm{x}$ & ††† \\
\hline 244, cTmOptBlue & ${ }^{\circ} \mathrm{C}$ & 25 & 28 & $\begin{array}{l}\text { optimum temperature of } \\
\text { bluegreens }\end{array}$ & $\mathrm{x}$ & $\mathrm{x}$ & $\mathrm{x}$ & $\mathrm{x}$ & $\mathrm{x}$ & $\dagger \dagger$ \\
\hline 246, cTmOptFish & ${ }^{\circ} \mathrm{C}$ & 25 & $\cdots$ & $\begin{array}{l}\text { optimum temperature of } \\
\text { fish }\end{array}$ & $\mathrm{x}$ & $\mathrm{x}$ & $\mathrm{x}$ & $\mathrm{x}$ & $\mathrm{x}$ & $\dagger$ \\
\hline 250, cTmOptZoo & ${ }^{\circ} \mathrm{C}$ & 25 & $\cdots$ & $\begin{array}{l}\text { optimum temperature of } \\
\text { zooplankton }\end{array}$ & $\mathrm{x}$ & $\mathrm{x}$ & $\mathrm{x}$ & $\mathrm{x}$ & $\mathrm{x}$ & $\pitchfork \dagger \dagger$ \\
\hline 253, cTurbDifNut & & 5 & $\cdots$ & $\begin{array}{l}\text { bioturbation factor for } \\
\text { diffusion }\end{array}$ & & & $\mathrm{x}$ & & & $\dagger$ \\
\hline 281, fDAssZoo & & 0.35 & 0.30 & $\begin{array}{l}\text { assimilation efficiency of } \\
\text { zooplankton }\end{array}$ & $\mathrm{x}$ & $\mathrm{x}$ & $\mathrm{x}$ & $\mathrm{x}$ & $\mathrm{x}$ & $\dagger \dagger \dagger$ \\
\hline 334, fRedMax & & 0.9 & $\cdots$ & $\begin{array}{l}\text { max reduction factor of } \\
\text { phosphorus adsorption } \\
\text { affinity }\end{array}$ & & & $\mathrm{x}$ & & & $\dagger$ \\
\hline 339, fRootVegWin & g & 0.6 & $\cdots$ & $\begin{array}{l}\text { root fraction outside } \\
\text { growing season }\end{array}$ & $\mathrm{x}$ & $\mathrm{x}$ & $\mathrm{x}$ & $\mathrm{x}$ & $\mathrm{x}$ & $\dagger \dagger$ \\
\hline 346, hDepthSusp & & 2 & $\cdots$ & $\begin{array}{l}\text { half-saturation of depth in } \\
\text { logistic function } \\
\text { controlling resuspension }\end{array}$ & $\mathrm{x}$ & $\mathrm{x}$ & $\mathrm{x}$ & $\mathrm{x}$ & $\mathrm{x}$ & $\dagger \dagger$ \\
\hline 351, hDZooFiJv & $\mathrm{g} / \mathrm{m}^{2}$ & 1.25 & 1.38 & $\begin{array}{l}\text { half-saturating } \\
\text { zooplankton biomass } \\
\text { for young fish } \\
\text { predation }\end{array}$ & $\mathrm{x}$ & $\mathrm{x}$ & $\mathrm{x}$ & $\mathrm{x}$ & $\mathrm{x}$ & $\dagger \dagger$ \\
\hline
\end{tabular}


TABLE 1. Continued.

\begin{tabular}{|c|c|c|c|c|c|c|c|c|c|c|}
\hline \multirow[b]{2}{*}{ Parameter ID } & \multirow[b]{2}{*}{ Unit } & \multicolumn{2}{|c|}{ Parameter value } & \multirow[b]{2}{*}{ Description } & \multicolumn{5}{|c|}{ Sensitivity allocation } & \multirow[b]{2}{*}{ Sensitivity } \\
\hline & & Default & Adjusted & & Chl $a$ & $\mathrm{TN}$ & $\mathrm{TP}$ & Veg & Zoo & \\
\hline 352, hFilt & $\mathrm{mg} \mathrm{DM} / \mathrm{L}$ & 1 & $\cdots$ & $\begin{array}{l}\text { half-saturation of food } \\
\text { concentration for } \\
\text { filtering }\end{array}$ & $\mathrm{x}$ & $\mathrm{x}$ & $\mathrm{x}$ & $\mathrm{x}$ & $\mathrm{x}$ & $t+t^{+}$ \\
\hline 357, hLRefVeg & $\mathrm{W} / \mathrm{m}^{2}$ & 17 & $\cdots$ & $\begin{array}{l}\text { half-saturation of light at } \\
20^{\circ} \mathrm{C}\end{array}$ & $\mathrm{x}$ & $\mathrm{x}$ & $\mathrm{x}$ & $\mathrm{x}$ & $\mathrm{x}$ & $\dagger \dagger \dagger$ \\
\hline 366, kDAssBent & $\mathrm{d}^{-1}$ & 0.1 & $\cdots$ & $\begin{array}{l}\text { maximum assimilation } \\
\text { rate for benthos }\end{array}$ & & $\mathrm{x}$ & & $\mathrm{x}$ & & $\dagger$ \\
\hline 367, kDAssFiAd & $\mathrm{d}^{-1}$ & 0.06 & 0.02 & $\begin{array}{l}\text { maximum assimilation } \\
\text { rate of adult fish }\end{array}$ & $\mathrm{x}$ & $\mathrm{x}$ & $\mathrm{x}$ & $\mathrm{x}$ & $\mathrm{x}$ & $t \dagger \dagger$ \\
\hline 368, kDAssFiJv & $d^{-1}$ & 0.12 & 0.09 & $\begin{array}{l}\text { maximum assimilation } \\
\text { rate of young fish }\end{array}$ & $\mathrm{x}$ & $\mathrm{x}$ & $\mathrm{x}$ & $\mathrm{x}$ & $\mathrm{x}$ & $\dagger \dagger$ \\
\hline 378, kDRespBlue & $d^{-1}$ & 0.03 & $\cdots$ & $\begin{array}{l}\text { maintenance respiration } \\
\text { constant of bluegreens }\end{array}$ & $\mathrm{x}$ & $\mathrm{x}$ & & $\mathrm{x}$ & $\mathrm{x}$ & $\dagger$ \\
\hline 385, kDRespVeg & $\mathrm{d}^{-1}$ & 0.02 & $\cdots$ & $\begin{array}{l}\text { dark respiration rate of } \\
\text { vegetation }\end{array}$ & $\mathrm{x}$ & $\mathrm{x}$ & $\mathrm{x}$ & $\mathrm{x}$ & $\mathrm{x}$ & $\dagger \dagger$ \\
\hline 386, kDRespZoo & $d^{-1}$ & 0.15 & 0.1 & $\begin{array}{l}\text { maintenance respiration } \\
\text { constant of } \\
\text { zooplankton }\end{array}$ & $\mathrm{x}$ & $\mathrm{x}$ & $\mathrm{x}$ & $\mathrm{x}$ & $\mathrm{x}$ & $\dagger \dagger$ \\
\hline 402, kMortBlueW & $\mathrm{d}^{-1}$ & 0.01 & 0.009 & $\begin{array}{l}\text { mortality constant of } \\
\text { bluegreens in water }\end{array}$ & $\mathrm{x}$ & & & & $\mathrm{x}$ & $\dagger$ \\
\hline 406, kMortFiJv & $d^{-1}$ & 0.00137 & 0.005 & $\begin{array}{l}\text { specific mortality of } \\
\text { young fish }\end{array}$ & $\mathrm{x}$ & & & $\mathrm{x}$ & $\mathrm{x}$ & $\dagger$ \\
\hline 410, kMortVegSum & $d^{-1}$ & 0.005 & $\cdots$ & $\begin{array}{l}\text { vegetation mortality rate } \\
\text { in spring and summer }\end{array}$ & & $\mathrm{x}$ & & $\mathrm{x}$ & & $\dagger$ \\
\hline 411, kMortZoo & $d^{-1}$ & 0.04 & $\cdots$ & $\begin{array}{l}\text { mortality constant of } \\
\text { zooplankton }\end{array}$ & $\mathrm{x}$ & $\mathrm{x}$ & & $\mathrm{x}$ & $\mathrm{x}$ & $\dagger \dagger$ \\
\hline 418, kPDifPO4 & $\mathrm{m}^{2} / \mathrm{d}$ & 0.000072 & 0.00004 & $\begin{array}{l}\mathrm{PO}_{4} \text { diffusion constant } \\
\quad(\mathrm{mol})\end{array}$ & & & $\mathrm{x}$ & & & $\dagger$ \\
\hline \multicolumn{11}{|l|}{ B) Not sensitive } \\
\hline 102, cLOptRefDia & $\mathrm{W} / \mathrm{m}^{2}$ & 54 & 80 & $\begin{array}{l}\text { optimum photosynthetic } \\
\text { active radiation for } \\
\text { diatoms at } 20^{\circ} \mathrm{C}\end{array}$ & & & & & & \\
\hline 191, cPrefGren & & 0.75 & 0.67 & selection factor for greens & & & & & & \\
\hline 255, cVNUptMaxBl & $\underset{\mathrm{DM}^{-1} \cdot \mathrm{d}}{\mathrm{mg} \mathrm{N}}$ & 0.07 & 0.12 & $\begin{array}{l}\text { maximum } \mathrm{N} \text { uptake } \\
\text { capacity of bluegreens }\end{array}$ & & & & & & \\
\hline 279, fDAssFiJv & & 0.4 & 0.3 & $\begin{array}{l}\mathrm{C} \text { assimilation efficiency } \\
\text { of young fish }\end{array}$ & & & & & & \\
\hline 344, fWinVeg & & 0.3 & 0.05 & $\begin{array}{l}\text { vegetation fraction } \\
\text { surviving in winter }\end{array}$ & & & & & & \\
\hline 371, kDMinDetS & $d^{-1}$ & 0.002 & 0.0021 & $\begin{array}{l}\text { decomposition constant of } \\
\text { detritus in sediment }\end{array}$ & & & & & & \\
\hline 372, kDMinDetW & $d^{-1}$ & 0.01 & 0.03 & $\begin{array}{l}\text { decomposition constant of } \\
\text { detritus in water }\end{array}$ & & & & & & \\
\hline
\end{tabular}

Notes: Default denotes the parameter value assigned by Janse (2005) and adjusted denotes the values assigned in the initial adjustment based on model performance with respect to observed lakes water quality. An $\mathrm{x}$ under sensitivity allocation denotes if the parameter was identified as sensitive for the given water quality variable according to the 90th percentile criteria. Sensitivity illustrates the summarized and ranked normalized sensitivity for each parameter across all water quality variables. Four daggers indicate high sensitivity and one dagger lower sensitivity, ranging from 0.1 to 4.2 , respectively. Units and descriptions are according to Janse (2005). Abbreviations are: Chl $a$, chlorophyll $a$; TN, total nitrogen; TP, total phosphorus; Veg, submerged vegetation coverage; Zoo, zooplankton; DM, dry matter; and W, Watt; Ellipses indicate no data was collected.

For the ensemble in general, the modeled water quality variation, represented by the span between the 5 th to 95th percentile of all runs, encapsulated the predominant part of the observations; more than $90 \%$ was captured for Veg and chl $a$ and approximately $70 \%$ for TN, TP, and Zoo (Fig. 5). TP exhibited the lowest coverage, and the model lacked the capability to simulate seasonal peak dynamics with the same order of amplitude between the lower winter concentrations and the higher summer concentrations as displayed by observations. For TN, the model successfully captured trends in concentrations during the entire period 1992-
2009, and the marked two-year concentration decrease between 1996 and 1998 was also captured by the model. However, each year, the summer and autumn concentrations were generally underestimated, with 5th percentile levels approaching zero. For Veg, the 5th and 95th percentile spanned the full range of submerged vegetation coverage each year, approaching 100\% coverage almost every summer, whereas P95 for chl $a$ showed more between-year variability with the highest and lowest summer concentrations occurring in 1992 (chl $a, 277 \mu \mathrm{g} / \mathrm{L}$ ) and 2005 (chl $a, 157 \mu \mathrm{g} / \mathrm{L})$, respectively (Fig. 5). 


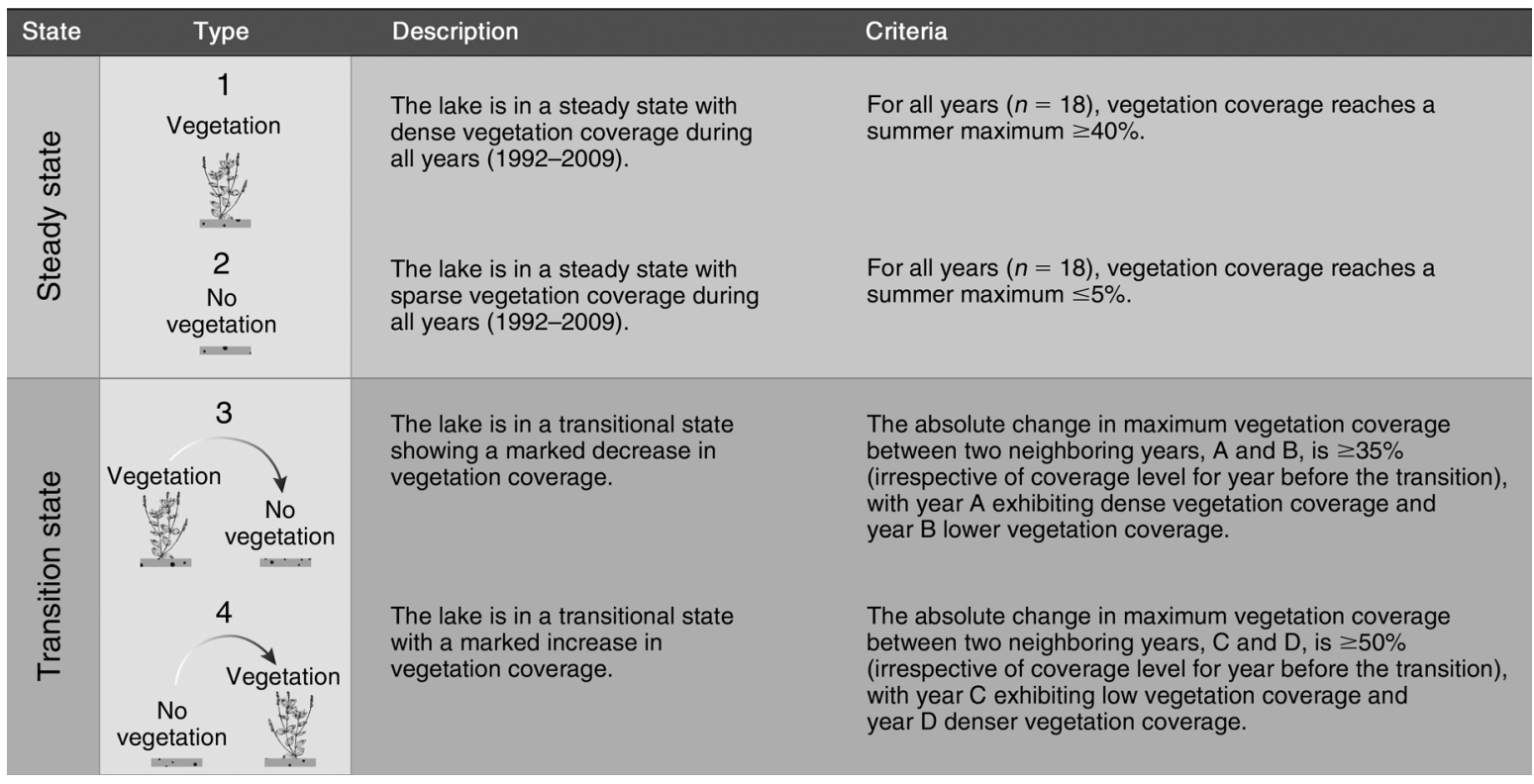

FIG. 3. Description and criteria applied to categorize simulated output into different types of lakes with respect to submerged vegetation coverage. Types 1-4 denote the lake type, which is referred to throughout the present study.

\section{Ecological regimes and variability}

For all water quality variables, significant differences $(P<0.001)$ were found when comparing mean concentrations between the ecological regime type 1 and 2. chl $a$ (type $1,0.98 \mu \mathrm{g} / \mathrm{L}$ and type $2,100.8 \mu \mathrm{g} / \mathrm{L}$ ) exhibited the highest difference of two orders of magnitude, whereas differences for TN (type 1, 0.7 $\mathrm{mg} / \mathrm{L}$ and type $2,2.3 \mathrm{mg} / \mathrm{L}$ ) and TP (type $1,0.02 \mathrm{mg} / \mathrm{L}$ and type $2,0.08 \mathrm{mg} / \mathrm{L}$ ) were four- and threefold, and only a modest difference emerging for Zoo (type 1, 0.43 $\mathrm{mg} / \mathrm{L}$ and type $2,0.47 \mathrm{mg} / \mathrm{L}$ ). For all four water quality variables, the variability indicated by the 5th to 95th percentile span was markedly wider for type 2 than for type 1 (Fig. 6).

During transition from higher to lower vegetation coverage (type 3), the mean concentrations of chl $a$ (type 3, from $17.9 \mu \mathrm{g} / \mathrm{L}$ to $38.8 \mu \mathrm{g} / \mathrm{L}$ ) and TN (type 3, from $1.55 \mathrm{mg} / \mathrm{L}$ to $2.34 \mathrm{mg} / \mathrm{L})$ increased significantly $(P<$ 0.001 ), whereas mean TP (type 3 , from $0.059 \mathrm{mg} / \mathrm{L}$ to $0.083 \mathrm{mg} / \mathrm{L}$ ) and Zoo (type 3, from $0.64 \mathrm{mg} / \mathrm{L}$ to 0.66 $\mathrm{mg} / \mathrm{L}$ ) before and after transition showed no significant differences ( $P=0.09$ and $P=0.62$, respectively; see Fig. 6). In contrast, an increase in vegetation coverage (type 4) was accompanied by a significant $(P<0.001)$ decrease in mean concentrations of all water quality variables: chl $a$ (type 4 , from $39.6 \mu \mathrm{g} / \mathrm{L}$ to $11.9 \mu \mathrm{g} / \mathrm{L}$ ), $\mathrm{TN}$ (from $2.58 \mathrm{mg} / \mathrm{L}$ to $1.67 \mathrm{mg} / \mathrm{L}$ ), TP (from $0.068 \mathrm{mg}$ / $\mathrm{L}$ to $0.038 \mathrm{mg} / \mathrm{L}$ ), and Zoo (from $0.63 \mathrm{mg} / \mathrm{L}$ to $0.56 \mathrm{mg}$ / L), respectively (Fig. 6). Chl $a$ exhibited the largest relative change in concentration with the transition to sparse vegetation (type 3 ), but chl $a$ was also associated with the greatest span between percentiles, indicating the greatest uncertainty (Fig. 7). For both transitions (type
3 and type 4 , respectively), the span between percentiles (5th and 95th) showed both a positive and a negative zooplankton response (Fig. 7), indicating both an increase and a decrease in zooplankton biomass with both transition types.

\section{Scenarios}

With progression (see Fig. 8, first row) from the current to the warmest simulated scenario $\left(6.0^{\circ} \mathrm{C}\right)$, the ensemble showed an absolute reduction of 17 percentage points in the fraction of runs of lake types categorized as steady and vegetation rich (type 1) and an increase in runs categorized as vegetation sparse (type 2). With increased nutrient load ( $+75 \%$ of $\mathrm{N}$ and $\mathrm{P}$ ) along with the warmest scenario, the fractions of type 1 and type 2 only changed slightly more $(\approx 20$ percentage points). For lakes in transition, only negligible changes occurred. With a reduction in nutrient loading $(-75 \%$ of $\mathrm{N}$ and $\mathrm{P})$ under current climatic conditions (see Fig. 8, first column), the fraction of runs categorized as type 1 exhibited the largest change and increased by 24 percentage points, while type 3 and type 4 decreased by approximately $8-10$ percentage points. In contrast, type 2 exhibited only a minor decrease $(\approx 5$ percentage points). Simulations of reduced nutrient loading and the highest temperature $\left(6.0^{\circ} \mathrm{C}\right)$ showed minor changes $(<8$ percentage points) for all types compared to base simulations of current nutrient loading and climate.

For the clear water, high density vegetation state (type 1), exhibiting low chl $a$ concentrations (95th percentile $<$ $20 \mu \mathrm{g} / \mathrm{L}$ ) across all simulated scenarios, the proportion of cyanobacteria increased for all nutrient loading regimes as warming progressed. The highest proportion (50th percentile, 63\%) was reached for the highest 
nutrient loading and warming scenario, being almost two-fold higher than under current temperature and nutrient loading (50th percentile, 37\%), whereas a reduction in nutrient loading in the warmest scenario yielded a similar (50th percentile, 39\%) proportion as current conditions (Fig. 9).

For the turbid, vegetation sparse state (type 2), the proportion of cyanobacteria was $>90 \%$ in the 25 th percentile for all simulated scenarios, showing a marked narrowing of the 5th to 95th percentile span with increasing warming (Fig. 9). At the current nutrient loading, the mean summer concentration of chl $a$ increased from $101 \mu \mathrm{g} / \mathrm{L}$ to $117 \mu \mathrm{g} / \mathrm{L}$ in the warmest scenario, while the highest mean summer chl $a$ concentration $(130 \mu \mathrm{g} / \mathrm{L})$ was reached in the warmest scenario with elevated nutrient loading. For both stages of transition (type 3 and type 4), scenarios with reduced nutrient loading exhibited a larger shift in the proportion of cyanobacteria compared to scenarios with increased nutrient loading (Fig. 9).

\section{Discussion}

Lake Arreskov has exhibited marked variations in water quality during the last two decades, which proved difficult to mimic with the initial manually adjusted set of model parameter values in PCLake (see Fig. 5, single line representation). Consequently, performance statistics were modest across all temporal scales (Table 2) compared to the range of performances in other studies reported by Arhonditsis and Brett (2004), although they were in the same order of magnitude as that achieved by recent applications of the model (i.e., chl $a R^{2}, 0.04$ [Fragoso Jr., et al. 2011]). In several published modeling studies (e.g., Janse and Aldenberg 1990, Elliott et al. 2006, Trolle et al. 2011) that typically covered a shorter time scale (1-6 years, but 14 years for Trolle et al. [2008]), the lakes being modeled did not exhibit the same marked variability and regime shifts as found across the two-decade scale in Lake Arreskov and were therefore somewhat easier to calibrate. With the compilation of an ensemble of model runs with multiple sets of parameter values sampled randomly within fixed intervals, we were able to encapsulate $70-90 \%$ of the observed concentrations of chl $a$, TN, TP, and Zoo and abundances of Veg (see Fig. 5, 5th and 95th percentile).

\section{Observed variability and modeled ecological regimes}

Causes and responses to the multiple regime shifts in Lake Arreskov have been subject to analysis before (e.g., Jensen et al. 2000, Jeppesen et al. 2003, Hansen et al. 2004), and the shifts have been attributed to several combined effects, such as interannual variations in external nutrient loading (three times higher TP loading in $1994[\approx 900 \mathrm{~kg}]$ than in $1996[\approx 300 \mathrm{~kg}]$ ) and climate $\left(3^{\circ} \mathrm{C}\right.$ higher summer mean water temperature in 2006 $\left[19^{\circ} \mathrm{C}\right]$ than in $\left.1993\left[15.8^{\circ} \mathrm{C}\right]\right)$, or changes in resuspension induced by changes in submerged vegetation, or by water level regulation or other implemented restoration interventions (Hansen 2002, Liboriussen et al. 2007). As these multiple contrasting regime periods may be viewed as distinct ecosystem states (high water clarity and high abundance of submerged vegetation contrasting loss of vegetation and turbid water [Scheffer et al. 1993]) triggered differently across time (Andersen et al. 2009), a single set of parameter values may constrain the conceptual capacity of the model required to render such marked variations in ecological regime types. By including the multiple sets of parameter combinations, encompassing states of either clear water dominated by macrophytes or turbid water dominated by phytoplankton, as well as transitional states, exhibiting either a marked decrease or increase in vegetation coverage (Fig. 6 ), we argue that our ensemble provides a more adequate representation of the variations observed in the Lake Arreskov ecosystem during an 18-year period.

Dynamics in water quality for transitional states (Fig. 7 ), simulated as increases in chl $a$, TP, and TN as the lake shifted from a vegetation rich to a vegetation sparse state or the reverse, correspond conceptually well with the interactions between chemistry and ecology reported in the literature (e.g., Jeppesen 1998), and the model also had a convincing performance for cyanobacteria. In years with denser vegetation coverage (1997, 2005, and 2006, where coverage ranged between $47-61 \%$ ), a proxy for type 1 , the observed mean summer fraction of cyanobacteria was $58 \%$, whereas for years with turbid water and lower vegetation coverage (1999, 2000, and 2004), a proxy for type 2, the fraction was $92 \%$. Corresponding proportions of cyanobacteria were captured by the ensemble (Fig. 9). Yet, the temporal dynamics occurring during the 18 observational years were not covered well by any of the individual simulations within the ensemble when assessed through an objective function in terms of goodness of fit (e.g., Arhonditsis and Brett 2004). This was somewhat surprising as various ecosystem replications are contained in the ensemble, including transitional states. However, identification of sensitive parameters was assessed as the average deviation in water quality variables between the simulation by the initial manually adjusted model and the simulation after changing parameter values $\pm 25 \%$ across the entire 18 -year time series. Parameters contributing to interannual dynamics (such as submerged vegetation collapses) may therefore not appear strongly in the ranked sensitivity (Fig. 4). Consequently, such parameters cannot have contributed to the span of simulated water quality variables as they were not subject to random value sampling in the ensemble. A future sensitivity analysis with focus on interannual dynamics (not least in vegetation coverage) may therefore further improve our understanding of the marked variability observed in the lake.

\section{Conceptual model constraints}

When evaluating the outcome of the sensitivity analysis, PCLake seemed to produce the all or nothing 

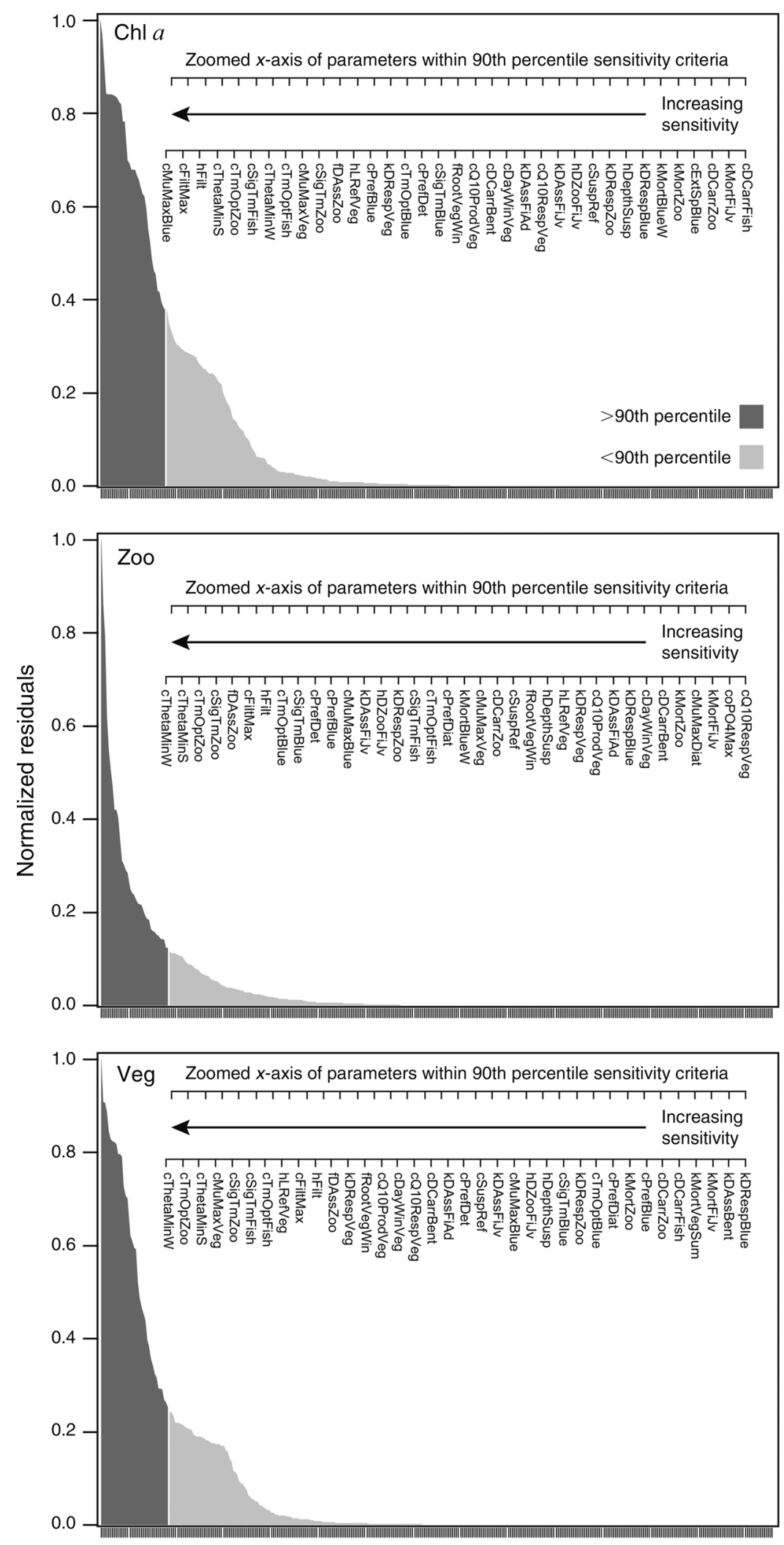

Parameters, $n=350$

FIG. 4. Sensitivity analysis output illustrated as normalized (0-1) and ranked deviations (residuals) between modeled water quality output from initial adjusted parameter values and parameter values changed $\pm 25 \%$. Water quality output (chlorophyll $a$ 


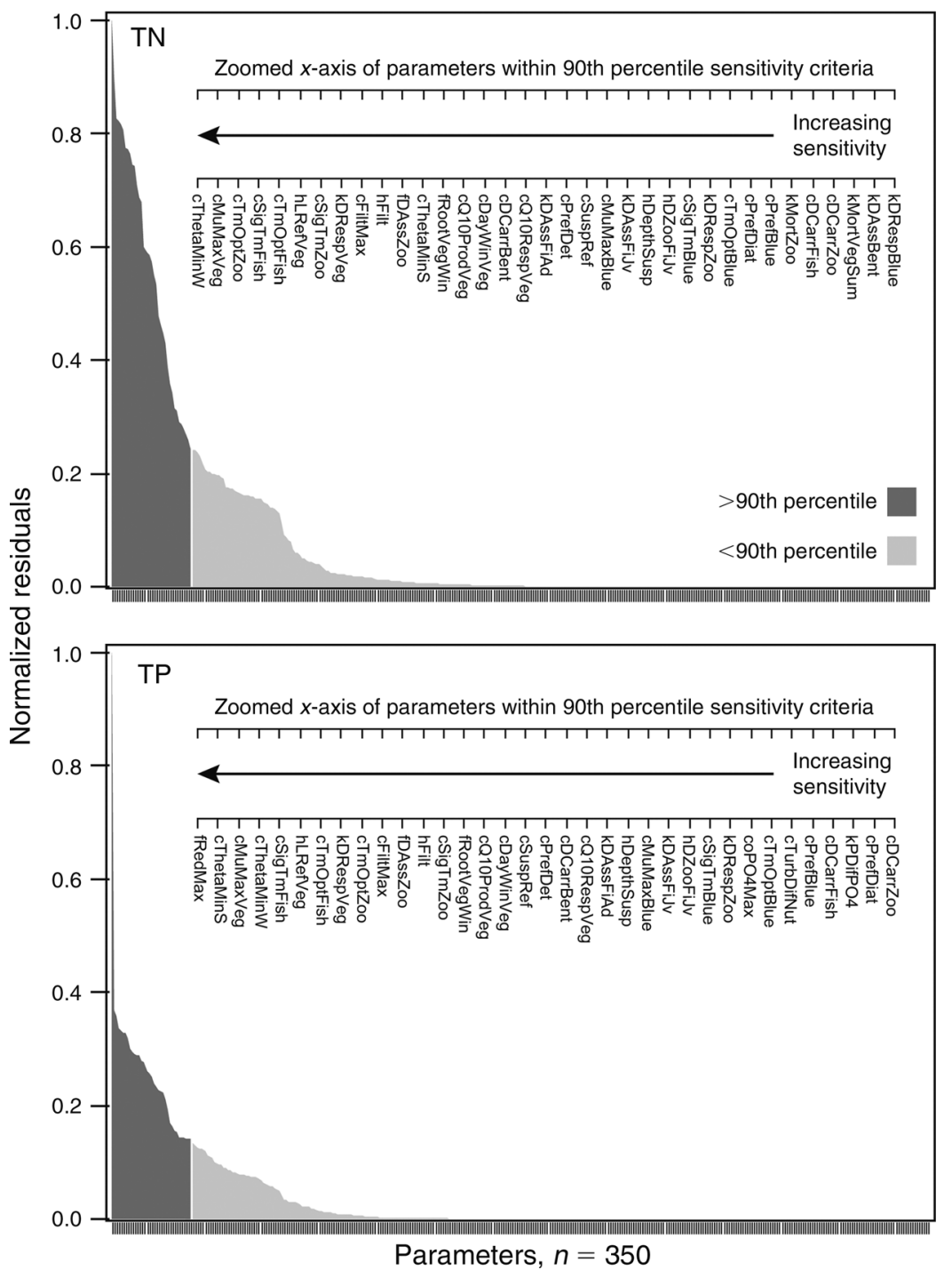

FIG. 4. Continued.

response in water quality variables emphasized by Mooij et al. (2010), and with no vertical gradients in the model (i.e., zero-dimensional water column), conceptual constraints may possibly have contributed to the difficulties in mimicking the multiple state shifts in the lake. Despite the lake's shallowness (1.9 $\mathrm{m}$ in mean depth), summer profile observations (unpublished data) showed gradients of dissolved oxygen in the water column with sporadic low levels $(<3 \mathrm{mg} / \mathrm{L})$ closest to the bottom, which may facilitate release of phosphorus from the sediment (Søndergaard et al. 2003). Such gradients are not incorporated in the model, and derived anoxic releases are therefore ignored as a mutual catalyst of regime shifts, despite the fact that phosphorus released from the sediment may constitute an important part of total loading (Søndergaard et al. 2013). Thus, it may also explain why simulated TP exhibited the lowest coverage of observed values in our ensemble (see Fig. 5, 5th and 95th percentiles), as seasonal peak dynamics were not being simulated with the same order of amplitude as the observations. Ongoing studies are currently implementing PCLake into FABM (Trolle et al. 2012), which in the near future will allow PCLake to be run in zero-

$[\mathrm{Chl} a]$, total nitrogen [TN], total phosphorus [TP], submerged vegetation coverage [Veg], and zooplankton [Zoo]) is represented by summer mean concentrations averaged across the full time series (i.e., 1992-2009). The $x$-axes represent ranked individual model parameters adjustable in calibration $(n=350)$. Dark gray area denotes the parameters contributing to 90 th percentile sensitivity with a corresponding zoomed $x$-axis presenting extracted sensitive parameters. See Table 1 for parameter descriptions. 
TABLE 2. Mean absolute relative error (RE, \%) and coefficient of determination $\left(R^{2}\right)$ between simulated model output and observations for daily, monthly, seasonal (months 5-9), and yearly time steps based on daily interpolated values from 1992 to 2009.

\begin{tabular}{|c|c|c|c|c|c|c|c|c|}
\hline \multirow[b]{2}{*}{ Variable } & \multicolumn{2}{|c|}{ Day } & \multicolumn{2}{|c|}{ Month } & \multicolumn{2}{|c|}{ Season } & \multicolumn{2}{|c|}{ Year } \\
\hline & $\mathrm{RE}$ & $R^{2}$ & $\mathrm{RE}$ & $R^{2}$ & $\mathrm{RE}$ & $R^{2}$ & $\mathrm{RE}$ & $R^{2}$ \\
\hline Chl $a$ & 110 & 0.04 & 99 & 0.05 & 60 & $0.11 \dagger$ & 51 & $0.05 \dagger$ \\
\hline $\mathrm{TP}$ & 47 & 0.06 & 46 & 0.06 & 40 & $<0.01 \dagger$ & 37 & $<0.01 \dagger$ \\
\hline $\mathrm{TN}$ & 37 & 0.03 & 37 & 0.03 & 40 & $<0.01 \dagger$ & 26 & $0.07 \dagger$ \\
\hline Veg & 91 & 0.03 & 90 & 0.03 & 73 & $0.19 \dagger$ & 86 & $0.21 \dagger$ \\
\hline Zoo & 81 & 0.05 & 75 & 0.06 & 40 & $0.06 \dagger$ & 48 & $0.11 \dagger$ \\
\hline
\end{tabular}

Note: See Table 1 for definitions of abbreviations.

$\dagger$ Not significant $(P>0.05)$.

dimensional, one-dimensional, and three-dimensional physical environments.

Ice-cover formation is also not included in PCLake. As Lake Arreskov is located in a temperate climate, it may exhibit periodic ice cover. Days with potential ice cover (defined as days during winter where the mean air temperature is $<1^{\circ} \mathrm{C}$ ) ranged between 22 days (winter 2006-2007) and 118 days (winter 1995-1996), but the implications for water clarity (through cascading effects of fish kill, reduced predation on zooplankton, and increased phytoplankton grazing [Balayla et al. 2010, Ruuhijärvi et al. 2010]) are not simulated. Ideally, the model should represent changes in species and size distribution and derived effects on grazing efficiency (i.e., filtering capacity and phytoplankton preferences in the model), as zooplankton communities change after cold winters (Balayla et al. 2010, Ruuhijärvi et al. 2010). Notably, $25 \%$ of the model parameters derived from the sensitivity analysis proved to relate to zooplankton dynamics (Table 1). Since these parameters are crucial to the overall simulated water quality output, our results emphasize the need to assess whether the zooplankton representation in the model is adequate, not least when applied to temperate shallow lakes where warming is expected to have particular influence on zooplankton communities (Jeppesen et al. 2009) and where future reductions in ice-cover formation may aggravate eutrophication (Jeppesen et al. 2010) beyond our current model predictions. Importantly, one-quarter of the parameters derived from the sensitivity analysis controlled influences of temperature in the model (Table 1 and Fig. 4). Thus, values assigned to these parameters should also be carefully considered because of the causal impacts on simulated output at elevated temperatures in climate change assessment studies.

\section{Methodological constraints}

Given the complex nature of PCLake, the model is characterized strongly by the nonuniqueness (equifinality) issue. Thus, multiple combinations of model parameter values may be equally representative of or optimal for the system being modeled, and no single set of model parameter values provides superior model performance relative to other combinations (Beven 2006). We used a simple classification method for subdivision of model parameter combinations into four individual categories (representing four types/states of a lake ecosystem). More complex methods, by which individual model runs can be identified and weighted (thus providing more robust likelihood estimates) according to performance measures (e.g., multiobjective functions), have been used in hydrological sciences such as GLUE (Beven and Freer 2001) or SUFI2 (Abbaspour et al. 2007). We also trialed a range of multiobjective functions, but when using these we were not able to find any subjective way to identify (and weight) model runs that represent the four different ecosystem states. Given the variability of the observed data from Lake Arreskov, the multiobjective functions were generally weak (as is typical for biological state variables of highly parameterized ecosystem models relative to more simple and physically based hydrological models) and therefore not readily distinctive between the four ecosystem states. Therefore, we found that the only objective way forward was classification of model runs into the four ecosystem states based on simple criteria for presence/absence of vegetation (which is thus a simple functional distinction and not based on values from an objective function). We do not claim that approaches enabling time-variant criteria to modify weights of individual model runs are not possible for complex ecosystem models as PCLake. However, this would require a comprehensive array of additional research activities in which, for example, brute-force methodologies could be trialed on highperformance computing facilities (HPC), thus enabling hundreds of thousands (or even millions) of parameter samplings in the parameter space of a complex ecosystem model.

\section{Future scenario implications for water management authorities}

In agreement with the anticipated effects of a warmer future climate on lake water quality suggested by other studies (Mooij et al. 2007, Jeppesen et al. 2010), our results showed an increase in the turbid, vegetation sparse lake type (type 2) as temperature increased (Fig. 8 ), with pronounced impact (increase in the probability of the turbid lake type) from $2.0^{\circ} \mathrm{C}$ to $6.0^{\circ} \mathrm{C}$, whereas a marked increase in the clear water, vegetation dense lake type (type 1) appeared when reducing the nutrient 

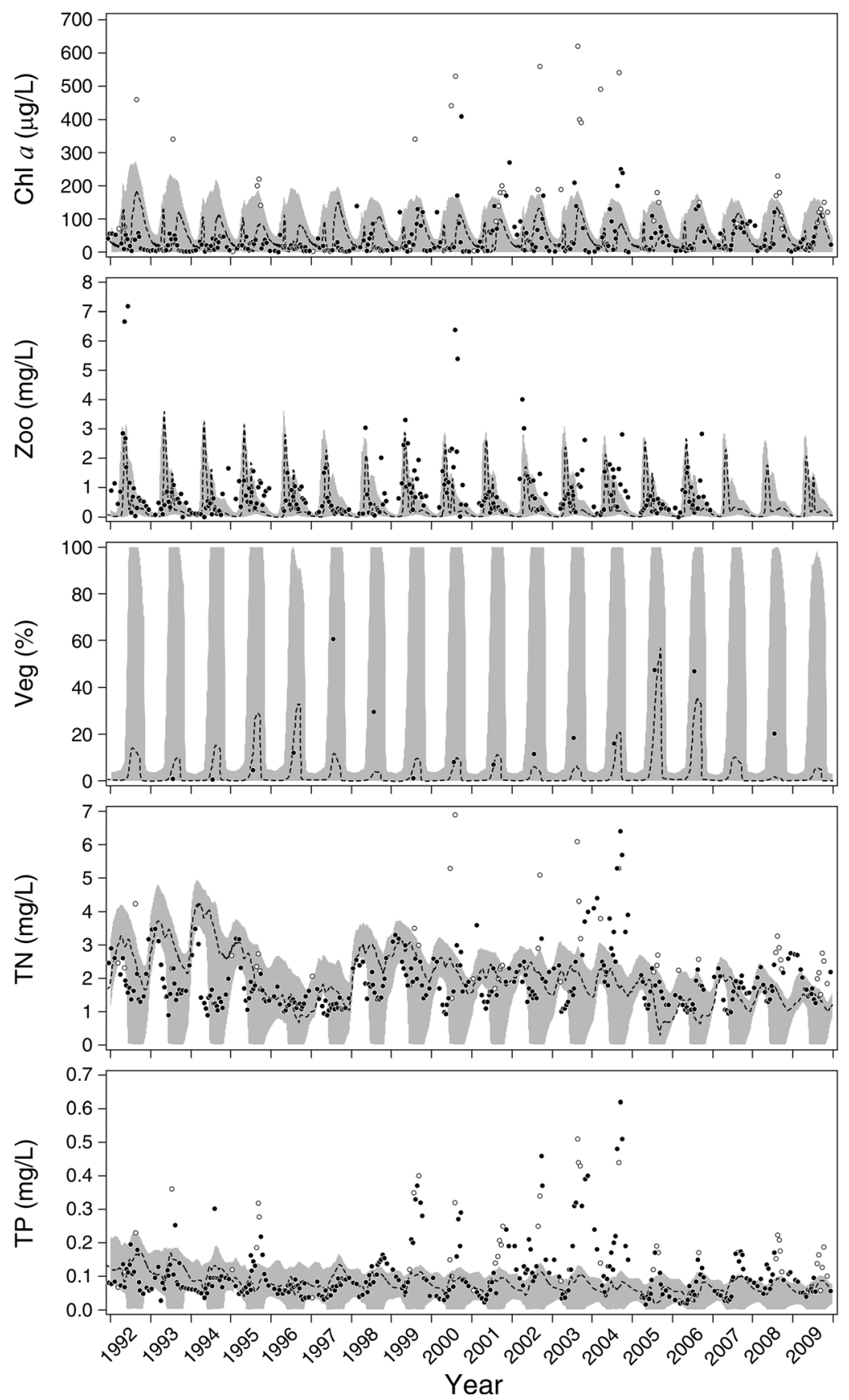

FIG. 5. Model performance against observed water quality. Filled gray circles denote observations $>0.6 \mathrm{~m}$, while open circles denote observations $<0.6 \mathrm{~m}$, conceptually out of reach for the model. Gray bands represent the span between the 5 th percentile and 95th percentile on a daily basis extracted from 900 simulations with randomly sampled parameter values for sensitive parameters $(n$ =43). Dashed lines represent model performance for the initial adjusted model. See Fig. 4 for definitions of abbreviations.

loading. A similar signal emerged for cyanobacteria, whose dominance increased with rising temperatures for all lake types (Fig. 9), which corresponds with the findings in other recent studies (Elliott 2012). Our results also showed a narrowing in the 5th to 95 th percentile range for the proportion of cyanobacteria with increasing temperature (Fig. 9), thus implying a greater certainty in our prediction of cyanobacteria dominance with progression of future warming. A key point for water management authorities is that our simulations indicate that maintenance of the ecological state of Lake Arreskov in a $6.0^{\circ} \mathrm{C}$ warming scenario requires a substantial reduction of the $\mathrm{N}$ and $\mathrm{P}$ loading (up to $75 \%$ of present levels). At $2.0^{\circ} \mathrm{C}$ warming, our simulations showed a $17 \%$ increase in the proportion of the turbid lake type with a parallel two-fold narrowing of 

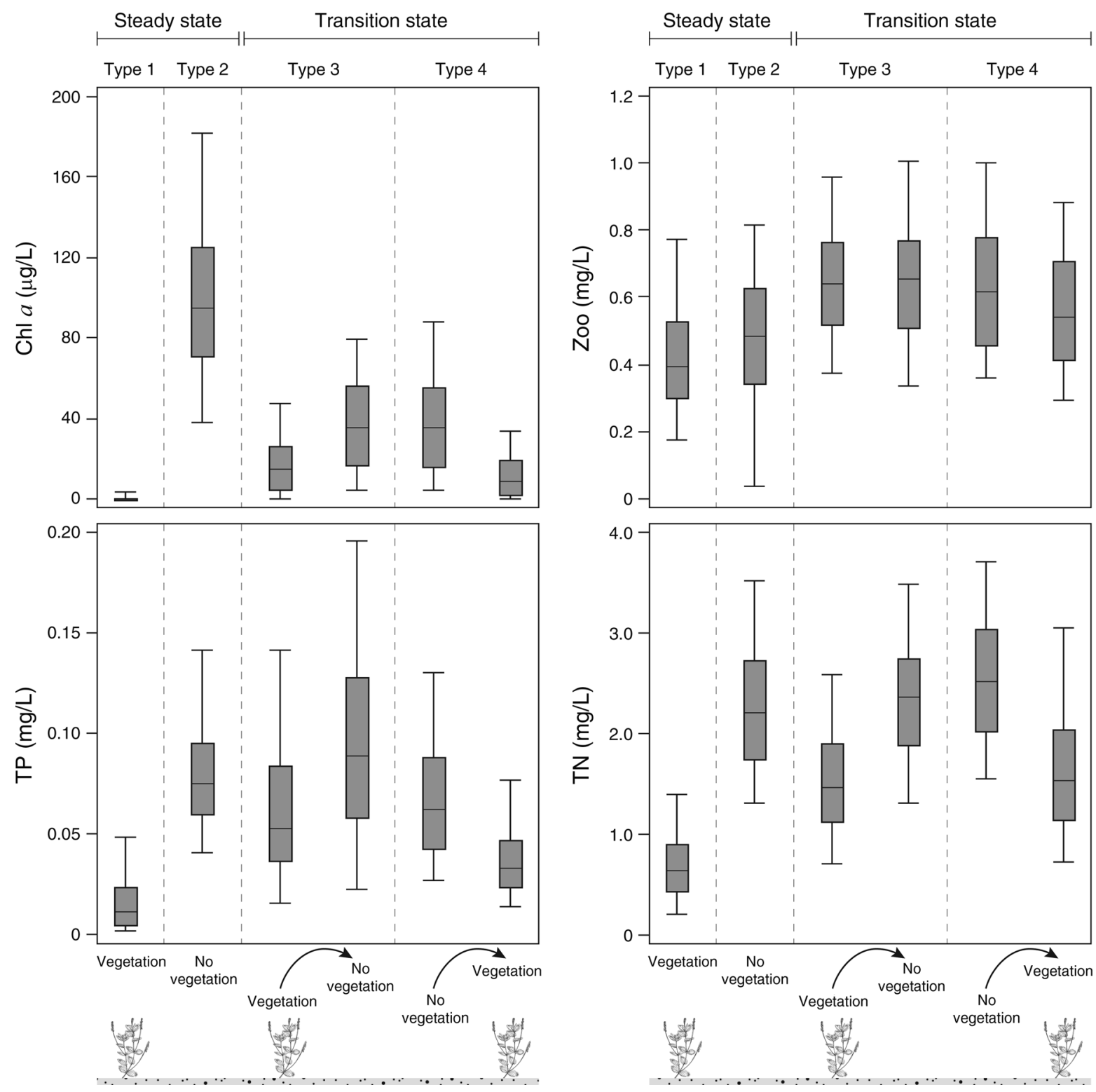

FIG. 6. Summer concentrations of simulated water quality in Lake Arreskov. The line inside boxes represents the 50th percentile, bottom and top of the box represent the 25th and 75th percentiles, respectively, and the whiskers represent the 5th and 95th percentiles. Values are shown for types 1-4 (see Fig. 3). Steady stages include simulated data for all years $(n=18)$, while transition stages only include simulated data for years when transitions occurred. See Fig. 4 for definitions of abbreviations.

the predicted span (5th to 95th percentile) of the cyanobacteria proportion, suggesting greater certainty of a turbid, cyanobacteria-dominated state even in a near-future warming scenario (Figs. 8 and 9).

The unique model ensemble approach presented in this study facilitates new ways of communicating future stressor impact assessments, and managers may illustrate the probability of achieving a certain ecological state. More importantly, however, the ensemble also prompts a more robust prediction than a single parameter combination by its inclusion of the potential large differences in scenario simulations between two equally representative sets of parameter combinations (due to differences in parameter sensitivities induced by, for instance, temperature or nutrient load). Hence, the approach would also be more appropriate, relative to using a single parameter set, for lakes where data availability for calibration and validation is sparse, and it further allows quantification of prediction uncertainties due to parameter estimation. The path of prediction relies, however, on the structural/conceptual composition of the model (i.e., how does the model account for changes), and future work should therefore focus on an ensemble approach with inclusion of multiple models as 

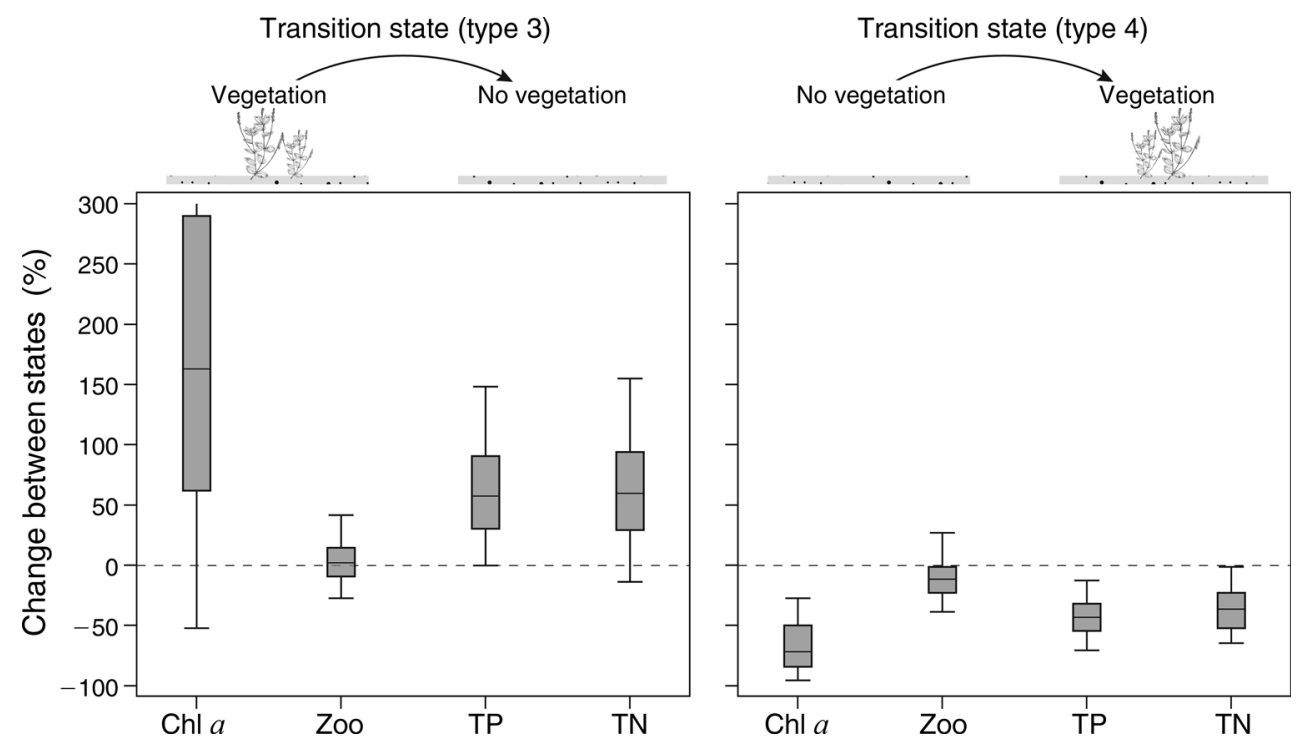

FIG. 7. Relative change in summer concentrations for type 3, exhibiting an increase in submerged vegetation coverage, and type 4, exhibiting a decrease in vegetation coverage (see Fig. 3). Box plots are as in Fig. 6. See Fig. 4 for definitions of abbreviations.

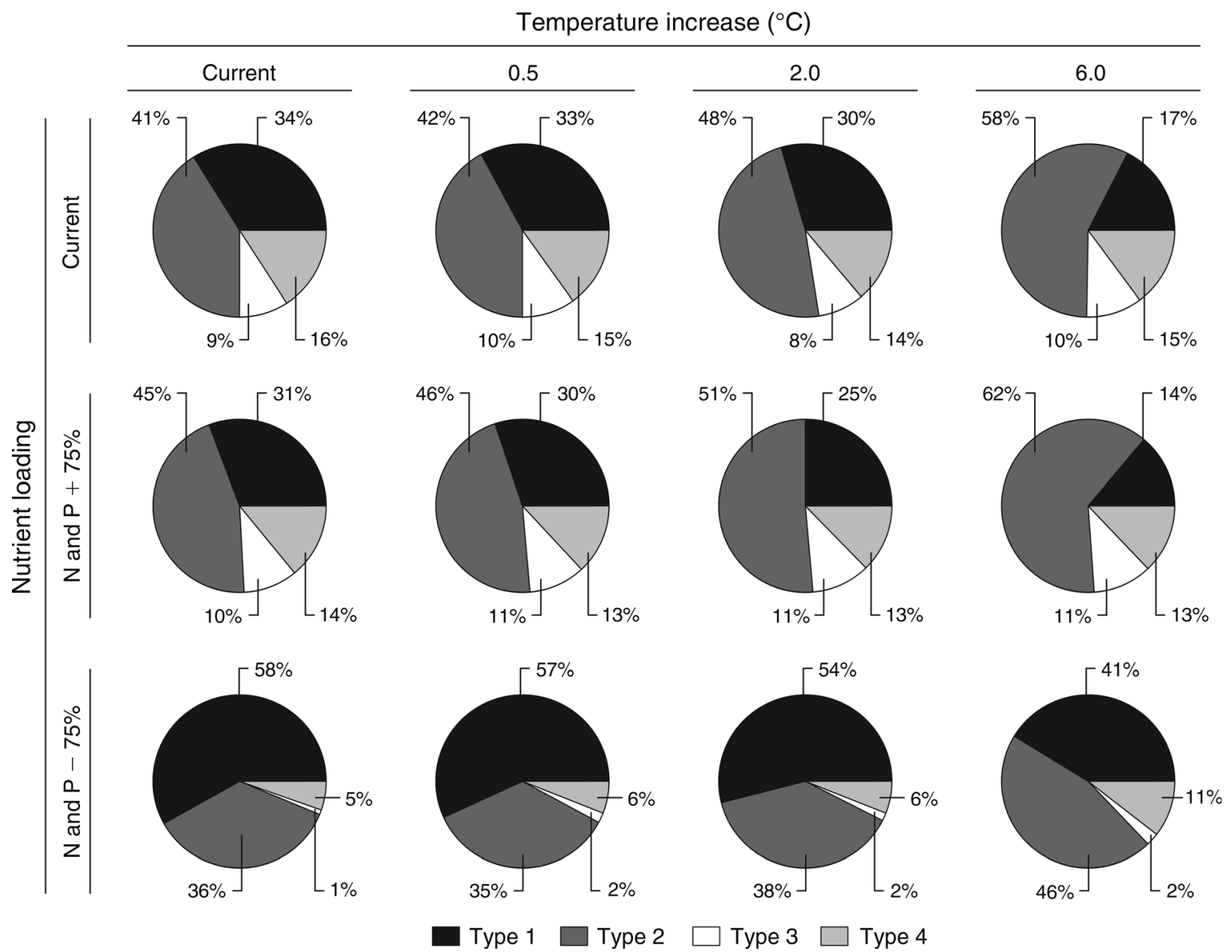

FIG. 8. Percentage of lake types (1-4; see Fig. 3) for simulated scenarios of temperature increase and changed nutrient loading. Temperature scenarios were produced by uniform transformation across seasons (i.e., delta change method from current climatic conditions) and scenarios on nutrient loading were produced by an increase or decrease in the daily nutrient loading of both nitrogen $(\mathrm{N})$ and phosphorus $(\mathrm{P})$ by $75 \%$ according to current loadings. 


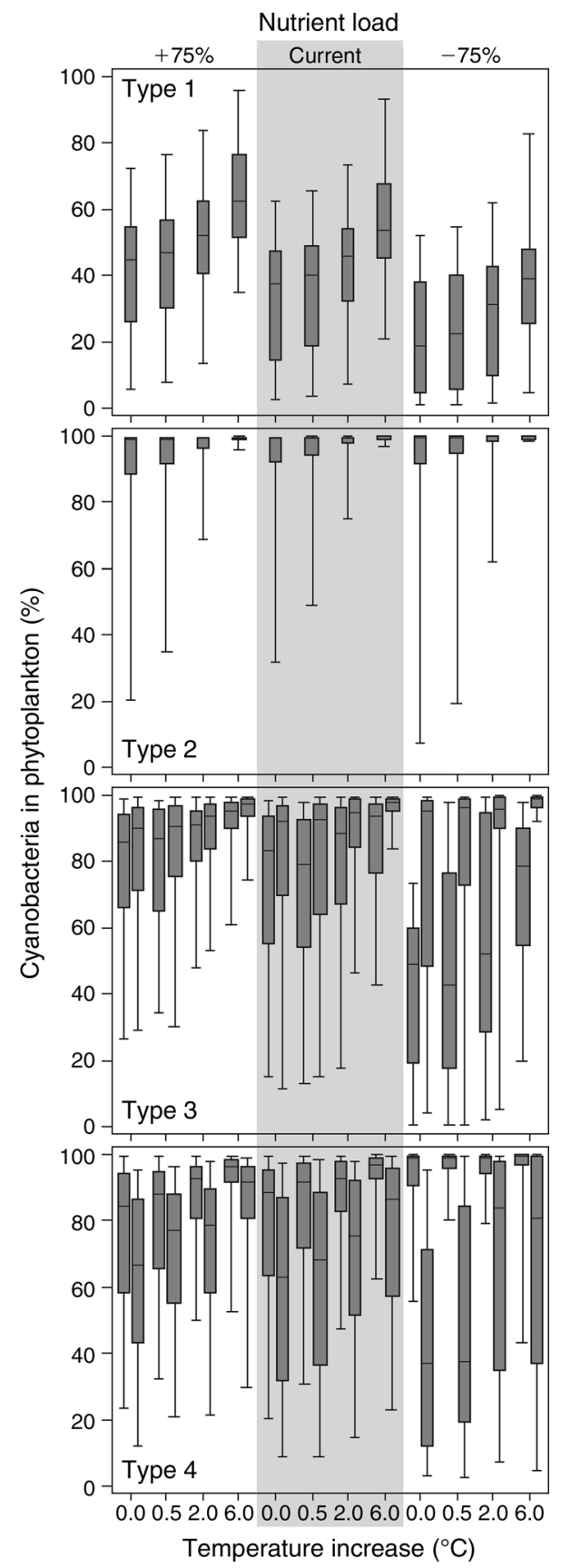

FIG. 9. Simulated scenarios for percentage of cyanobacteria in phytoplankton for the different lake types (see Fig. 3). Box plots are as in Fig. 6. For types 3 and 4, each scenario includes two boxes representing the percentage of cyanobacteria before and after transition, respectively.

pointed out by Trolle et al. (2014). This will enable utilization of decades of individual model niche development (Mooij et al. 2010) and allow exploration of future lake water quality with wider conceptual spans. That one specific model is too narrow and ignores certain conceptualizations (perhaps) essential for pre- dictability (Mooij et al. 2010) is thereby to some extent mitigated.

\section{ACKNOWLEDGMENTS}

This study was supported by CRES (Danish Strategic Research Council), CLEAR (a Villum Kann Rasmussen Centre of Excellence project), EU REFRESH, and CIRCE. We thank Anne Mette Poulsen for valuable editorial comments.

\section{Literature Cited}

Abbaspour, K. C., J. Yang, I. Maximov, R. Siber, K. Bogner, J. Mieleitner, J. Zobrist, and R. Srinivasan. 2007. Modelling hydrology and water quality in the pre-alpine/alpine Thur watershed using SWAT. Journal of Hydrology 333:413-430.

Andersen, T., J. Carstensen, E. Hernández-García, and C. M. Duarte. 2009. Ecological thresholds and regime shifts: approaches to identification. Trends in Ecology and Evolution 24:49-57.

Arhonditsis, G. B., and M. T. Brett. 2004. Evaluation of the current state of mechanistic aquatic biogeochemical modeling. Marine Ecology Progress Series 271:13-26.

Arhonditsis, G. B., G. Perhar, W. Zhang, E. Massos, M. Shi, and A. Das. 2008. Addressing equifinality and uncertainty in eutrophication models. Water Resources Research 44:W01420.

Balayla, D., T. L. Lauridsen, M. Søndergaard, and E. Jeppesen. 2010. Larger zooplankton in Danish lakes after cold winters: are winter fish kills of importance? Hydrobiologia 646:159172.

Beven, K. 2006. A manifesto for the equifinality thesis. Journal of Hydrology 320:18-36.

Beven, K., and J. Freer. 2001. Equifinality, data assimilation, and uncertainty estimation in mechanistic modelling of complex environmental systems using the GLUE methodology. Journal of Hydrology 249:11-29.

Cappelen, J., C. Kern-Hansen, and K. Sarup. 2007. Technical Report 06-12. Danish Meteorological Institute, Copenhagen, Denmark.

Delpla, I., A. V. Jung, E. Baures, M. Clement, and O. Thomas. 2009. Impacts of climate change on surface water quality in relation to drinking water production. Environment International 35:1225-1233.

Ellermann, T., H. V. Andersen, R. Bossi, J. Christensen, P. Løfstrøm, C. Monies, L. Grundahl, and C. Geels. 2010. Atmosfærisk deposition 2009. Danmarks Miljøundersøgelser Aarhus Universitet, Aarhus, Denmark. [In Danish.]

Elliott, J., I. Jones, and S. Thackeray. 2006. Testing the sensitivity of Phytoplankton communities to changes in water temperature and nutrient load, in a temperate lake. Hydrobiologia 559:401-411.

Elliott, J. A. 2012. Is the future blue-green? A review of the current model predictions of how climate change could affect pelagic freshwater cyanobacteria. Water Research 46:13641371.

Falconer, I., and A. Humpage. 2005. Health risk assessment of cyanobacterial (blue-green algal) toxins in drinking water. International Journal of Environmental Research and Public Health 2:43-50.

Fragoso, Jr., C. R., D. M. L. Motta Marques, T. F. Ferreira, J. H. Janse, and E. H. van Nes. 2011. Potential effects of climate change and eutrophication on a large subtropical shallow lake. Environmental Modelling and Software 26:1337-1348.

Fyns Amt. 2006. Natura 2000 basisanalyse. Habitatområde H105, EFFuglebeskyttelsesområde 78 Arreskov Sø. Naturog Vandmiljøafdelingen, Odense, Denmark.

Hamilton, D. P., and S. G. Schladow. 1997. Prediction of water quality in lakes and reservoirs. Part I-Model description. Ecological Modelling 96:91-110. 
Hansen, K. S. 2002. Changes in biological structure of the hypertrophic Lake Arreskov after diversion of wastewater and biomanipulation. Page 75 in International Conference on Limnology of Shallow Lakes. Veszprém University Press, Balatonfüred, Hungary.

Hansen, K. S., S. R. Christensen, H. Brendstrup, L. Hildebrandt, J. Christiansen, B. Jacobsen, and M. Kruse. 2004. Arreskov Sø 2003. VANDMILJØovervågning. Fyns Amt Natur- og Vandmiljøafdelingen, Odense, Denmark. [In Danish.]

Hansen, L. B., M. Källstrøm, S. L. Jørgensen, and B. Hasler. 2011. Vådområders omkostningseffektivitet. Danmarks Miljøundersøgelser, Aarhus Universitet, Aarhus, Denmark. [In Danish.]

Hoffmann, C. C., A. Baattrup-Pedersen, E. Jeppesen, S. L. Amsinck, and P. Clausen. 2004. Overvågning af Vandmiljøplan II Vådområder 2004. 103 s. -Faglig rapport fra DMU nr. 518. Danmarks Miljøundersøgelser, Denmark. [In Danish.]

Imerito, A. 2007. Dynamic reservoir simulation model, DYRESM v4. Centre for Water Research, University of Western Australia, Perth, Australia.

Janse, J., and T. Aldenberg. 1990. Modelling phosphorus fluxes in the hypertrophic Loosdrecht Lakes. Aquatic Ecology 24:69-89.

Janse, J. H. 1997. A model of nutrient dynamics in shallow lakes in relation to multiple stable states. Hydrobiologia 342-343:1-8.

Janse, J. H. 2005. Model studies on the eutrophication of shallow lakes and ditches. Wageningen University, Wageningen, The Netherlands.

Janse, J. H., L. N. De Senerpont Domis, M. Scheffer, L. Lijklema, L. Van Liere, M. Klinge, and W. M. Mooij. 2008. Critical phosphorus loading of different types of shallow lakes and the consequences for management estimated with the ecosystem model PCLake. Limnologica 38:203-219.

Janse, J. H., M. Scheffer, L. Lijklema, L. Van Liere, J. S. Sloot, and W. M. Mooij. 2010. Estimating the critical phosphorus loading of shallow lakes with the ecosystem model PCLake: sensitivity, calibration and uncertainty. Ecological Modelling 221:654-665.

Janse, J. H., and L. van Liere. 1995. PCLake: a modelling tool for the evaluation of lake restoration scenarios. Water Science and Technology 31:371-374.

Jensen, J. P., M. Søndergaard, E. Jeppesen, R. B. Olsen, F. Landkildehus, T. L. Lauridsen, L. Sortkjær, and A. M. Poulsen. 2000. Søer 1999. Danmarks Miljøundersøgelser, Silkeborg, Denmark. [In Danish.]

Jeppesen, E. 1998. The ecology of shallow lakes-trophic interactions in the pelagial. Ministry of Environment and Energy, National Environmental Research Institute, Silkeborg, Denmark.

Jeppesen, E., J. P. Jensen, M. Søndergaard, H. Kjeld Sandby, P. H. Møller, H. U. Rasmussen, V. Norby, and S. E. Larsen. 2003. Does resuspension prevent a shift to a clear state in shallow lakes during reoligotrophication? Limnology and Oceanography 48:1913-1919.

Jeppesen, E., et al. 2009. Climate change effects on runoff, catchment phosphorus loading and lake ecological state, and potential adaptations. Journal of Environmental Quality 38:1930-1941.

Jeppesen, E., et al. 2010. Interaction of climate and eutrophication. Pages 119-151 in M. Kernan, R. Battarbee, and B. Moss, editors. Changing climate and changing freshwaters: a European perspective. Blackwell, Hoboken, New Jersey, USA.

Jeppesen, E., J. PederJensen, M. Søndergaard, T. Lauridsen, and F. Landkildehus. 2000. Trophic structure, species richness and biodiversity in Danish lakes: changes along a phosphorus gradient. Freshwater Biology 45:201-218.

Jin, X., Q. Xu, and C. Huang. 2005. Current status and future tendency of lake eutrophication in China. Science in China Series C: Life Sciences 48:948-954.

Jørgensen, S. E. 1994. Models as instruments for combination of ecological theory and environmental practice. Ecological Modelling 75-76:5-20.

Jørgensen, S. E., and G. Bendoricchio. 2001. Fundamentals of ecological modelling. Volume 21. Elsevier Science Limited, Amsterdam, The Netherlands.

Kosten, S., et al. 2012. Warmer climates boost cyanobacterial dominance in shallow lakes. Global Change Biology 18:118126.

Kronvang, B., G. Ærtebjerg, R. Grant, P. Kristensen, M. Hovmand, and J. Kirkegaard. 1993. Nationwide monitoring of nutrients and their ecological effects: state of the Danish aquatic environment. AMBIO 22:176-187.

Lauridsen, T., M. Søndergaard, J. P. Jensen, E. Jeppesen, and T. B. Jørgensen. 2007. Undersøgelser i søer. NOVANA og DEVANO overvågningsprogram. Dammarks Miljøundersøgelser, Aarhus Universitet, Denmark. [In Danish.]

Liboriussen, L., M. Søndergaard, and E. Jeppesen. 2007. Sørestaurering i Danmark. Del II: Eksempelsamling. Danmarks Miljøundersøgelser, Aarhus University, Aarhus, Denmark. [In Danish.]

Meinshausen, M., N. Meinshausen, W. Hare, S. C. B. Raper, K. Frieler, R. Knutti, D. J. Frame, and M. R. Allen. 2009. Greenhouse-gas emission targets for limiting global warming to $2^{\circ} \mathrm{C}$. Nature $458: 1158-1162$.

Mooij, W., et al. 2010. Challenges and opportunities for integrating lake ecosystem modelling approaches. Aquatic Ecology 44:633-667.

Mooij, W. M., J. H. Janse, L. N. De Senerpont Domis, S. Hülsmann, and B. W. Ibelings. 2007. Predicting the effect of climate change on temperate shallow lakes with the ecosystem model PCLake. Pages 443-454 in R. D. Gulati, E. Lammens, N. Pauw, and E. Donk, editors. Shallow lakes in a changing world. Springer Netherlands, Heidelberg, Germany.

Moss, B., et al. 2011. Allied attack: climate change and eutrophication. Inland Waters 1:101-105.

Nielsen, K., et al. 2000. Areal informations systemet-AIS. Energiministeriet, Danmarks Miljøundersøgelser, Denmark. [In Danish.]

Olivier, J. G. J., G. Janssens-Maenhout, and J. A. H. W. Peters. 2012. Trends in global $\mathrm{CO}_{2}$ emissions 2012 Report. Netherlands Environmental Assessment Agency, The Hague, The Netherlands.

Paerl, H. W., and J. Huisman. 2008. Blooms like it hot. Science 320:57-58.

Refsgaard, J. C., et al. 2014. A framework for testing the ability of models to project climate change and its impacts. Climatic Change 122:271-282.

Ruuhijärvi, J., M. Rask, S. Vesala, A. Westermark, M. Olin, J. Keskitalo, and A. Lehtovaara. 2010. Recovery of the fish community and changes in the lower trophic levels in a eutrophic lake after a winter kill of fish. Hydrobiologia 646:145-158.

Sandby, K. 1998. Arreskov Sø. Pages 105-115 in M. Søndergaard, E. Jeppesen, and J. P. Jensen, editors. Sørestaurering i Danmark: metoder erfaringer og anbefalinger. Miljøstyrelsen: Miljønyt 28, Denmark. [In Danish.]

Scheffer, M., S. H. Hosper, M. L. Meijer, B. Moss, and E. Jeppesen. 1993. Alternative equilibria in shallow lakes. Trends in Ecology and Evolution 8:275-279.

Schmolke, A., P. Thorbek, D. L. DeAngelis, and V. Grimm. 2010. Ecological models supporting environmental decision 
making: a strategy for the future. Trends in Ecology and Evolution 25:479-486.

Smith, V. H., and D. W. Schindler. 2009. Eutrophication science: where do we go from here? Trends in Ecology and Evolution 24:201-207.

Søndergaard, M., R. Bjerring, and E. Jeppesen. 2013. Persistent internal phosphorus loading during summer in shallow eutrophic lakes. Hydrobiologia 710:95-107.

Søndergaard, M., J. P. Jensen, and E. Jeppesen. 2003. Role of sediment and internal loading of phosphorus in shallow lakes. Hydrobiologia 506-509:135-145.

Søndergaard, M., E. Jeppesen, T. L. Lauridsen, C. Skov, E. H. Van Nes, R. Roijackers, E. Lammens, and R. O. B. Portielje. 2007. Lake restoration: successes, failures and long-term effects. Journal of Applied Ecology 44:1095-1105.

Stocker, T. F. 2013. The closing door of climate targets. Science 339:280-282.

Trenberth, K. E., et al. 2007. Observations: surface and atmospheric climate change. Pages 235-336 in S. Solomon, D. Qin, M. Manning, Z. Chen, M. Marquis, K. B. Averyt, M. Tignor, and H. L. Miller, editors. Climate change 2007: the physical science basis. Contribution of Working Group I to the Fourth Assessment Report of the Intergovernmental
Panel on Climate Change. Cambridge University Press, Cambridge, UK.

Trolle, D., A. Elliott, W. M. Mooij, J. H. Janse, K. Bolding, D. P. Hamilton, and E. Jeppesen. 2014. Advancing forecasts of phytoplankton responses to climate change through ensemble modelling. Environmental Modelling and Software. In press.

Trolle, D., et al. 2012. A community-based framework for aquatic ecosystem models. Hydrobiologia 683:25-34.

Trolle, D., D. P. Hamilton, C. A. Pilditch, I. C. Duggan, and E. Jeppesen. 2011. Predicting the effects of climate change on trophic status of three morphologically varying lakes: implications for lake restoration and management. Environmental Modelling and Software 26:354-370.

Trolle, D., H. Skovgaard, and E. Jeppesen. 2008. The water framework directive: setting the phosphorus loading target for a deep lake in Denmark using the 1D lake ecosystem model DYRESM-CAEDYM. Ecological Modelling 219:138-152.

UN. 2012. The United Nations world water development report 4: managing water under uncertainty and risk. UNESCO, Paris, France. 